Article

\title{
Vanadium(IV) Complexes with Methyl-Substituted 8-Hydroxyquinolines: Catalytic Potential in the Oxidation of Hydrocarbons and Alcohols with Peroxides and Biological Activity
}

Joanna Palion-Gazda ${ }^{1}$, André Luz ${ }^{2,3}$, Luis R. Raposo ${ }^{2,3} \mathbb{D}^{\mathbb{D}}$, Katarzyna Choroba ${ }^{1} \mathbb{D}$, Jacek E. Nycz ${ }^{1} \mathbb{D}$,

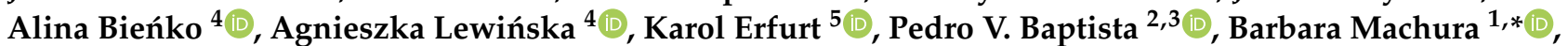
Alexandra R. Fernandes ${ }^{2,3, * D}$, Lidia S. Shul'pina ${ }^{6}$, Nikolay S. Ikonnikov ${ }^{6}$ and Georgiy B. Shul'pin ${ }^{7,8, *(D)}$

1 Institute of Chemistry, University of Silesia, Szkolna 9, 40-006 Katowice, Poland; joanna.palion-gazda@us.edu.pl (J.P.-G.); katarzyna.choroba@us.edu.pl (K.C.); jacek.nycz@us.edu.pl (J.E.N.)

2 Associate Laboratory i4HB-Institute for Health and Bioeconomy, NOVA School of Science and Technology, NOVA University Lisbon, 2819-516 Caparica, Portugal; af.luz@campus.fct.unl.pt (A.L.); 1.raposo@campus.fct.unl.pt (L.R.R.); pmvb@fct.unl.pt (P.V.B.)

3 UCIBIO-Applied Molecular Biosciences Unit, Department of Life Sciences, NOVA School of Science and Technology, NOVA University Lisbon, 2819-516 Caparica, Portugal

check for updates

Citation: Palion-Gazda, J.; Luz, A.; Raposo, L.R.; Choroba, K.; Nycz, J.E.; Bieńko, A.; Lewińska, A.; Erfurt, K.; V. Baptista, P.; Machura, B.; et al. Vanadium(IV) Complexes with Methyl-Substituted

8-Hydroxyquinolines: Catalytic Potential in the Oxidation of Hydrocarbons and Alcohols with Peroxides and Biological Activity. Molecules 2021, 26, 6364. https:// doi.org/10.3390/molecules26216364

Academic Editor: Bartolo Gabriele

Received: 24 September 2021 Accepted: 18 October 2021 Published: 21 October 2021

Publisher's Note: MDPI stays neutral with regard to jurisdictional claims in published maps and institutional affiliations.

Copyright: (c) 2021 by the authors. Licensee MDPI, Basel, Switzerland. This article is an open access article distributed under the terms and conditions of the Creative Commons Attribution (CC BY) license (https:/ / creativecommons.org/licenses/by/ $4.0 /)$.
4 Faculty of Chemistry, University of Wroclaw, F. Joliot-Curie 14, 50-383 Wroclaw, Poland; alina.bienko@chem.uni.wroc.pl (A.B.); agnieszka.lewinska@chem.uni.wroc.pl (A.L.)

5 Department of Chemical Organic Technology and Petrochemistry, Silesian University of Technology, Krzywoustego 4, 44-100 Gliwice, Poland; karol.erfurt@polsl.pl

6 A.N. Nesmeyanov Institute of Organoelement Compounds, Russian Academy of Sciences, Ulitsa Vavilova 28, 119991 Moscow, Russia; shulpina@ineos.ac.ru (L.S.S.); ikonns@ineos.ac.ru (N.S.I.)

7 N.N Semenov Federal Research Center for Chemical Physics, Russian Academy of Sciences, Ulitsa Kosygina 4, 119991 Moscow, Russia

8 Chair of Chemistry and Physics, Plekhanov Russian University of Economics, Stremyannyi Pereulok 36, 117997 Moscow, Russia

* Correspondence: barbara.machura@us.edu.pl (B.M.); ma.fernandes@fct.unl.pt (A.R.F.); gbsh@mail.ru (G.B.S.)

\begin{abstract}
Methyl-substituted 8-hydroxyquinolines (Hquin) were successfully used to synthetize five-coordinated oxovanadium(IV) complexes: [VO(2,6-(Me $)_{2}$-quin $\left.)_{2}\right]$ (1), [VO(2,5-(Me $)_{2}$-quin $\left.)_{2}\right]$ (2) and $\left[\mathrm{VO}(2-\mathrm{Me}-q u i n)_{2}\right]$ (3). Complexes 1-3 demonstrated high catalytic activity in the oxidation of hydrocarbons with $\mathrm{H}_{2} \mathrm{O}_{2}$ in acetonitrile at $50{ }^{\circ} \mathrm{C}$, in the presence of 2-pyrazinecarboxylic acid (PCA) as a cocatalyst. The maximum yield of cyclohexane oxidation products attained was $48 \%$, which is high in the case of the oxidation of saturated hydrocarbons. The reaction leads to the formation of a mixture of cyclohexyl hydroperoxide, cyclohexanol and cyclohexanone. When triphenylphosphine is added, cyclohexyl hydroperoxide is completely converted to cyclohexanol. Consideration of the regioand bond-selectivity in the oxidation of n-heptane and methylcyclohexane, respectively, indicates that the oxidation proceeds with the participation of free hydroxyl radicals. The complexes show moderate activity in the oxidation of alcohols. Complexes $\mathbf{1}$ and $\mathbf{2}$ reduce the viability of colorectal (HCT116) and ovarian (A2780) carcinoma cell lines and of normal dermal fibroblasts without showing a specific selectivity for cancer cell lines. Complex 3 on the other hand, shows a higher cytotoxicity in a colorectal carcinoma cell line (HCT116), a lower cytotoxicity towards normal dermal fibroblasts and no effect in an ovarian carcinoma cell line (order of magnitude HCT116 > fibroblasts > A2780).
\end{abstract}

Keywords: vanadium(IV) complexes; biological activity; catalytic properties; 8-hydroxyquinoline; cytotoxicity studies

\section{Introduction}

In the last three decades, vanadium coordination compounds have received increasing interest due to their structural features [1-44], catalytic applications [21-33,45,46] and 
medicinal importance [33-44,47-63]. Particular attention has been paid to bis-chelated $\mathrm{V}^{\mathrm{IV}} \mathrm{O}$ and $\mathrm{V}^{\mathrm{V}} \mathrm{O}$ complexes of the general formula $\left[\mathrm{V}^{\mathrm{IV}} \mathrm{O}(\mathrm{N} \cap \mathrm{O})_{2}\right]$, [ $\mathrm{V}^{\mathrm{IV}} \mathrm{O}(\mathrm{N} \cap \mathrm{O})_{2}$ (solvent)] and $\left[\mathrm{V}^{\mathrm{V}} \mathrm{O}(\mathrm{OR})(\mathrm{N} \cap \mathrm{O})_{2}\right]$. Among them there is the vanadium maltolate complex [VO(ethylm altolate)2] which entered phase IIa clinical trials as an antidiabetic agent [56]. For $\mathrm{V}^{\mathrm{IV}} \mathrm{O}$ complexes bearing bidentate picolinate ligands, it was found that their pharmacological potential is strongly dependent on the structural modification of organic ligands and ligand arrangement around the metal center [54,57-61]. Exemplarily, the introduction of an electron-withdrawing halogen atom or electron-donating alkyl group at the fifth or third position of the pyridine ring leads to stronger insulin-enhancing activity of [ $\mathrm{VO}$ (picolinate $\left.)_{2}\right]$ and $\left[\mathrm{VO}(\text { picolinate })_{2}\right.$ (solvent) $]$ in comparison with $\left[\mathrm{VO}(\text { picolinate })_{2}\left(\mathrm{H}_{2} \mathrm{O}\right)\right]$. On the contrary, investigations of the substituent effect on the antiproliferative potential of vanadium complexes $\left[\mathrm{V}^{\mathrm{V}} \mathrm{O}(\mathrm{OMe})(\mathrm{N} \cap \mathrm{O})_{2}\right]$ bearing 8-hydroxyquinoline ligands on HCT116 and A2780 cancer cell lines, showed that the introduction of substituents into the 8-hydroxyquinoline backbone at 5- and 5,7-positions induces a reduction of the antiproliferative effect in relation to $\left[\mathrm{VO}(\mathrm{OMe})(\text { quin })_{2}\right]$, and the complexes $\left[\mathrm{V}^{\mathrm{V}} \mathrm{O}(\mathrm{OMe})(\mathrm{N} \cap \mathrm{O})_{2}\right]$ with hydroxyquinoline (quin) substituted only in the 5-position were more cytotoxic than those with substituents in the 5,7-positions of the quin backbone. Nevertheless, as all the vanadium(V) complexes $\left[\mathrm{V}^{\mathrm{V}} \mathrm{O}(\mathrm{OR})(\mathrm{N} \cap \mathrm{O})_{2}\right]$ with 8-hydroxyquinoline derivatives showed a significantly lower $\mathrm{IC}_{50}$ towards the A2780 cell line, other than oxovanadium and dioxovanadium complexes previously reported [62], these systems deserve further intensive studies. What is also important, is that monomeric oxidovanadium $(\mathrm{V})$ complexes $\left[\mathrm{VO}(\mathrm{OMe})(\mathrm{N} \cap \mathrm{O})_{2}\right]$ with nitroor halogen-substituted quinolin-8-olate ligands were found to be very promising in view of their catalytic properties. These complexes exhibit high catalytic activity toward the oxidation of inert alkanes to alkyl hydroperoxides by $\mathrm{H}_{2} \mathrm{O}_{2}$ in aqueous acetonitrile, with the yield of oxygenate products up to $39 \%$ and a TON of 1730 for $1 \mathrm{~h}$ [63].

In continuation of our studies on monomeric oxovanadium complexes with bidentate monoanionic ligands $[62,63]$, we present herein the biological and catalytic potential of three oxovanadium(IV) complexes with methyl-substituted 8-hydroxyquinolines, they are $\left[\mathrm{VO}\left(2,6-(\mathrm{Me})_{2} \text {-quin }\right)_{2}\right](\mathbf{1}),\left[\mathrm{VO}\left(2,5-(\mathrm{Me})_{2} \text {-quin }\right)_{2}\right]$ (2) and [VO(2-Me-quin $\left.)_{2}\right]$ (3). Two of them ( 1 and 2 ) have been obtained for the first time, while compound 3 , the X-ray structure of which has been presented previously [64], was included to obtain more reliable structure-activity relationships for these systems. In contrast to the previously reported $\left[\mathrm{V}^{\mathrm{V}} \mathrm{O}(\mathrm{OMe})(\mathrm{N} \cap \mathrm{O})_{2}\right]$ with 8-hydroxyquinoline derivatives bearing substituents in the 5or 5,7-positions of the quin backbone, all the complexes here presented contain a vanadium(IV) ion and they are five-coordinated, which was evidenced by the X-ray diffraction analysis, EPR and UV-Vis spectroscopy. The catalytic potential of complexes 1-3 was examined for the oxidation of alkanes with $\mathrm{H}_{2} \mathrm{O}_{2}$ and compared with the activity of the classic system vanadate ion plus pyrazine-carboxylic acid (PCA). To evaluate the antiproliferative effect of complexes 1-3, HCT116 and A2780 cancer cell lines, and normal dermal fibroblasts were used.

\section{Results and Discussion}

\subsection{Synthesis}

To synthetize the oxidovanadium complexes with methyl-substituted 8-hydroxyquin olines, $\left[\mathrm{VO}\left(2,6-(\mathrm{Me})_{2} \text {-quin }\right)_{2}\right](\mathbf{1}),\left[\mathrm{VO}\left(2,5-(\mathrm{Me})_{2} \text {-quin }\right)_{2}\right](\mathbf{2})$, the previously reported procedure based on the reaction of bis(acetylacetonato)oxidovanadium(IV) with the corresponding 8-hydroxyquinoline derivative in open air was employed [62,63]. Remarkably, in the reaction with the use of quinH, 5-Cl-quinH, 5- $\mathrm{NO}_{2}$-quinH, 5,7-Cl 2 -quinH, 5,7-(Me) ${ }_{2}$-quinH, 5,7-Cl,I-quinH and 5,7-I 2 -quinH, 5,7-(Me) $)_{2}$-quinH, the vanadium(IV) of the starting $\left[\mathrm{VO}(\mathrm{acac})_{2}\right]$ undergoes oxidation by molecular oxygen and the acetylacetonato ligands are exchanged by the corresponding quinolin-8-olate ions to give six-coordinated $\left[\mathrm{V}^{\mathrm{V}} \mathrm{O}(\mathrm{OMe})(\mathrm{N} \cap \mathrm{O})_{2}\right]$. In contrast, the reactions of [ $\left.\mathrm{VO}(\mathrm{acac})_{2}\right]$ with 2-Me-quinH, 2,6-(Me $)_{2}-$ quinH and 2,5-(Me $)_{2}$-quinH resulted in the formation of five-coordinated $\left[\mathrm{V}^{\mathrm{IV}} \mathrm{O}(\mathrm{N} \cap \mathrm{O})_{2}\right]$. It indicates that the methyl-functionalization of quinH strengthen its coordination capacity 
to the V(IV) ion, and steric hindrance induced by the methyl group at the 2-position in the pyridine ring facilitates the formation of five-coordinated complexes.

\subsection{Molecular Structure}

Perspective views of the molecular structures of $\mathbf{1}$ and $\mathbf{2}$ together with the atom numbering are depicted in Figure 1. The atoms $\mathrm{V}(1)$ and $\mathrm{O}(2)$ in the structure $\mathbf{1}$ are located on a twofold crystallographic axis, thus the molecule $\left[\mathrm{VO}\left(5,6-(\mathrm{Me})_{2} \text {-quin }\right)_{2}\right]$ has crystallographically-imposed twofold symmetry.

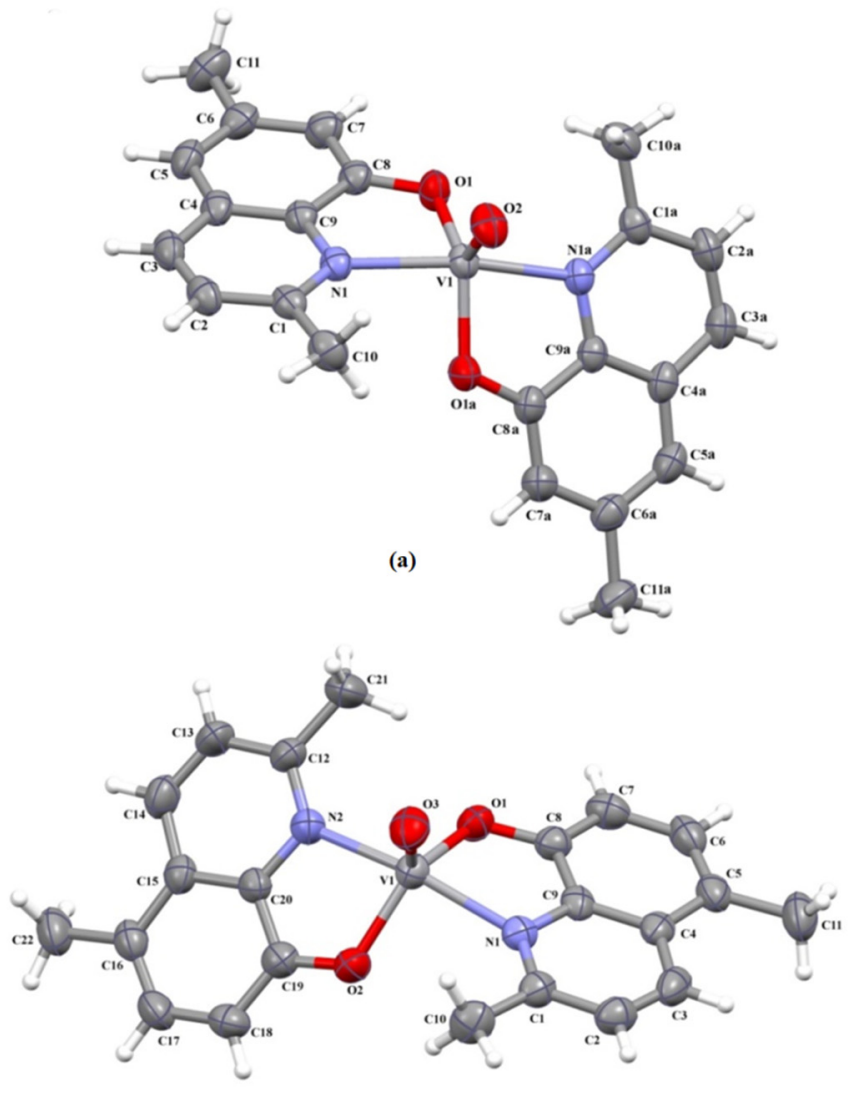

(b)

Figure 1. The molecular structures of $\mathbf{1}$ [symmetry code: $(\mathbf{a})=-x, y, 1 / 2-z]$ (a) and $\mathbf{2}(\mathbf{b})$. Displacement ellipsoids are drawn at the $50 \%$ probability level.

The five-coordinated vanadium(IV) ion adopts a coordination geometry lying between square pyramidal and trigonal bipyramidal. The angular structural index parameter $\tau$ [65], expressed as the difference between the two largest angles divided by 60 , has a value of 0.57 for $\mathbf{1}$ and 0.56 for 2 . The atom $\mathrm{V}(1)$ is shifted $\sim 0.6 \AA$ towards the oxo ion from the least-squares plane defined by the nitrogen and oxygen atoms of two quinolin-8-olate bidentate ligands. The bite angle of the chelating ligand is $\sim 80^{\circ}$ (Tables S1-S3, Supplementary Materials), and the dihedral angle between the least-squares planes formed by the organic ligands is equal to $60.38(4)^{\circ}$ for 1 and 50.32(3) ${ }^{\circ}$ for 2 . This kind of coordination geometry seems to be typical for $\left[\mathrm{VO}(\mathrm{N} \cap \mathrm{O})_{2}\right]$ bearing two $\mathrm{N}, \mathrm{O}$-donor bidentate ligands, contrary to $[\mathrm{VO}(\mathrm{O} \cap \mathrm{N} \cap \mathrm{N} \cap \mathrm{O})]$ of tetradentate Schiff base ligands in which fivecoordinated vanadium(IV) generally displays a distorted square-pyramidal environment with a basal square plane constituted by the two iminic nitrogen and two phenoxide oxygen atoms $[4,6,64,66-82]$ (Table S7, Supplementary Materials). The V $=\mathrm{O}[1.590(2)$ and 1.595(3) $\AA]$, V-O [1.921(1) and 1.924(2) $\AA$ ] and V-N [2.122(2) and 2.125(2) $\AA]$ bond lengths in 1 and 2 (Tables S1 and S2) are in good agreement with those reported for five-coordinated vanadyl compounds (Tables S3 and S7, Supplementary Materials). More detailed structural 
parameters of the designed complexes are included in Tables S4-S6 and Figures S3-S8 in Supplementary Materials.

The phase purity of $\mathbf{1}$ and $\mathbf{2}$ was evidenced by comparing the powder X-ray diffraction (PXRD) patterns of the powdery sample with those generated by simulation based on single-crystal structures. As shown in Figure S9, the bulk powder samples give patterns consistent with those obtained theoretically from the single-crystal structure.

\subsection{EPR Spectroscopy}

The oxidation state of vanadium in complexes $1-3$ was confirmed by the EPR spectra (Figure 2). The X-and Q-band EPR powder spectra of all complexes were recorded at room temperature. The $\mathrm{X}$-band spectrum shows intense central field broad structured bands with no detectable hyperfine structure at $g=1.982$ for $\mathbf{1}, 1.986$ for $\mathbf{2}$ and 1.996 for $\mathbf{3}$. The Q-band spectrum presents slightly resolved peaks, and the nature of the peaks is the same as in the X-band. The $77 \mathrm{~K}$ powder EPR spectra recorded at the X-band show that there is a slight increase in the signal intensity.

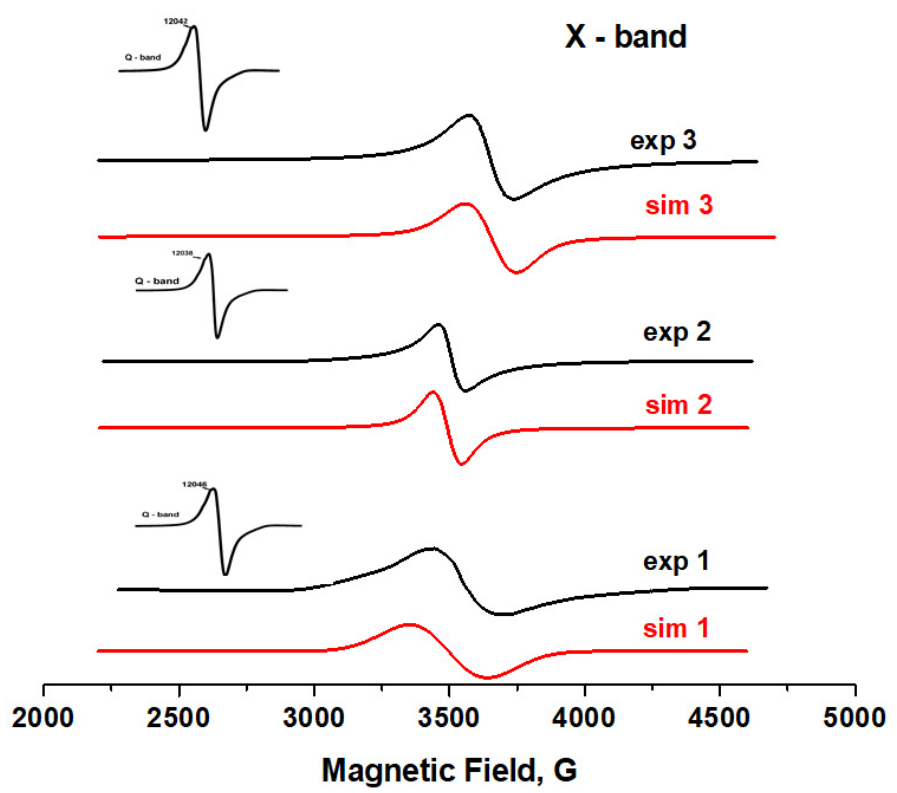

Figure 2. The X-band EPR spectra of 1-3 at $77 \mathrm{~K}$ together with the spectrum calculated by computer simulation of the experimental spectra with spin Hamiltonian parameters given in the text.

EPR frozen solution spectra of compounds 1-3 in DMSO (Figure 3) and $\mathrm{CH}_{3} \mathrm{CN}$ (Figure S10) show eight lines of hyperfine splitting of a parallel and perpendicular orientation, proving the interaction of $S=1 / 2$ with the nucleus spin of one vanadium and hence the formation of mononuclear compounds. The spectra of these mononuclear compounds may be simulated using the spin Hamiltonian parameters $\mathrm{g}_{\mathrm{x}}=\mathrm{g}_{\mathrm{y}}=1.979, \mathrm{~g}_{\mathrm{z}}=1.942$, $A_{x}=A_{y}=65 G, A_{z}=180 G$ for $1, g_{x}=g_{y}=1.977, g_{z}=1.958, A_{x}=A_{y}=52 G, A_{z}=169 G$ for 2, and $g_{x}=g_{y}=1.994, g_{z}=1.946, A_{x}=A_{y}=50 G, A_{z}=169 G$ for 3, respectively, which are typical for oxidovanadium(IV) compounds with an analogous $\mathrm{N}_{2} \mathrm{O}_{2}$ donor set of the ligands in the vanadium xy plane $[38,83,84]$, and in agreement with the molecular structure determined by X-ray crystal structure studies of $\mathbf{1}-\mathbf{3}$. 


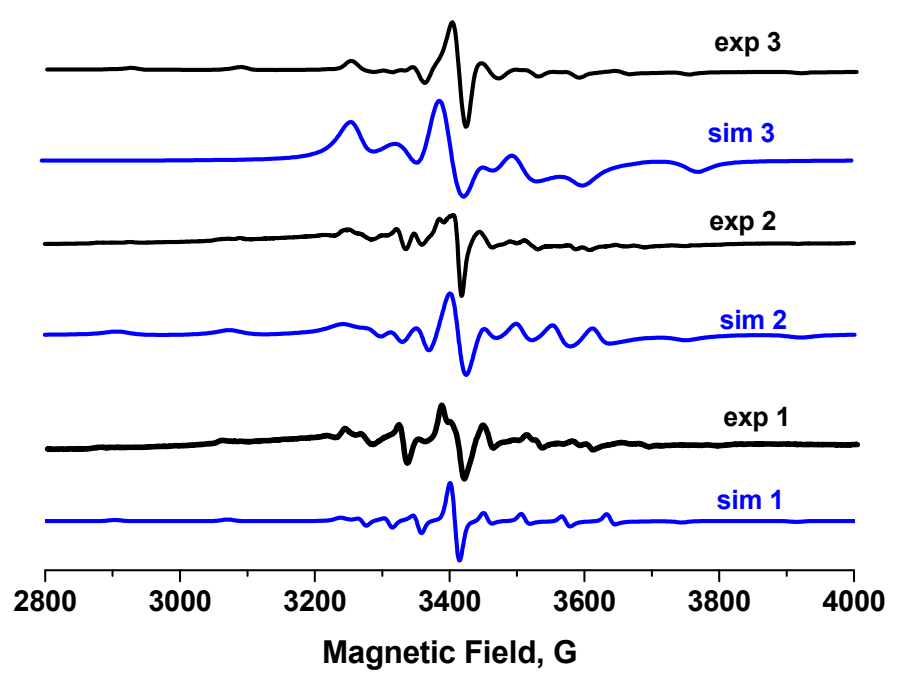

Figure 3. EPR frozen solution spectra (at $77 \mathrm{~K}$ ) of compounds 1-3; in aqueous 2\% DMSO.

In order to investigate the stability of the studied complexes, EPR spectra were recorded depending on the time (Figure 4). The constant position of bands confirms the stability of the V(IV) complexes in the solution.
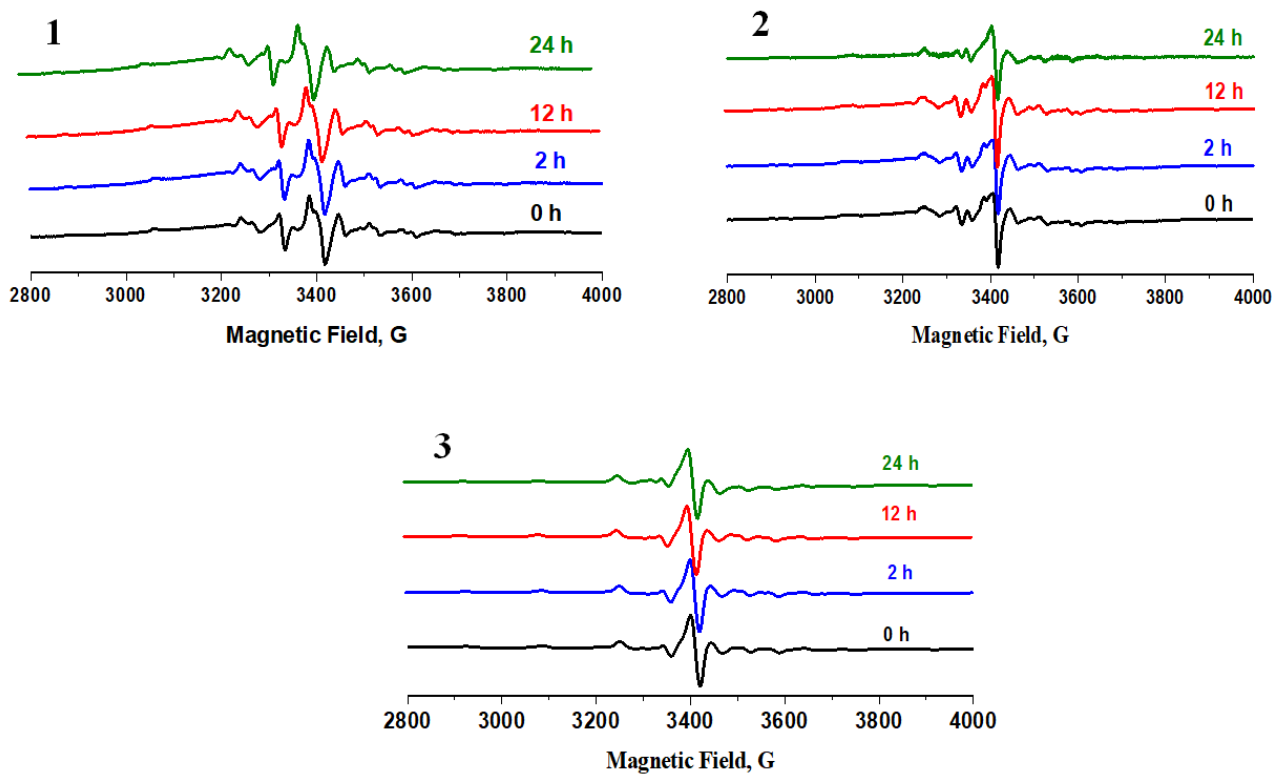

Figure 4. EPR stability spectra (frozen solution at $77 \mathrm{~K}$ in aqueous $2 \%$ DMSO) of compounds 1-3. Spectra were recorded every for $24 \mathrm{~h}$.

\subsection{Absorption Spectroscopy}

The yellowish-brown tetravalent $d^{1}$ complexes 1 and 3 display three ligand-field transitions $d_{x y} \rightarrow d_{x z}, d_{y z}$ and $d_{x y} \rightarrow d_{\mathrm{x}}{ }^{2}-\mathrm{y}^{2}$ and $d_{x y} \rightarrow d_{\mathrm{z}}{ }^{2}$ at 701,585 and $523 \mathrm{~nm}$ for 1 and 744, 572 and $501 \mathrm{~nm}$ for 3 . In the case of 2, only two bands of low intensity in the range $500-850 \mathrm{~nm}$, are observed. An expected a third transition attributed to $d_{x y} \rightarrow d_{\mathrm{z}}{ }^{2}$ is most likely masked by the intense ligand-metal charge-transfer (LMCT) transition with a maximum at $398 \mathrm{~nm}$. In the spectra of $\mathbf{1}$ and 3, the absorptions assigned transitions from the $p_{\pi}$ orbital of the phenolate oxygen to $d_{\pi}$ orbitals of the vanadium center (LMCT) occur at 380 and $383 \mathrm{~nm}$, respectively. The higher energy bands of $\mathbf{1 - 3}$, are attributable to the spin-allowed ligand centered transitions (IL) $\pi \rightarrow \pi^{*}$ of quinolin-8-olate (Figure S11, Supplementary Materials). 
UV-Vis spectroscopy was also used to study the stability of the five-coordinated oxidovanadium(IV) complexes in solution, and UV-Vis spectra of 1-3 in DMSO and $\mathrm{CH}_{3} \mathrm{CN}\left(10^{-4} \mathrm{M}\right)$ were collected once every two hours over $24 \mathrm{~h}$ at room temperature. As observed, the main bands remained constant in the electronic spectra, indicating stability of the V(IV) complexes in solution (Figures 5 and S12, Supplementary Materials).

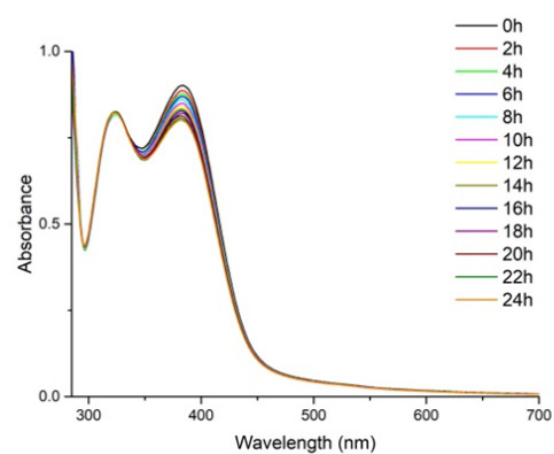

(a)

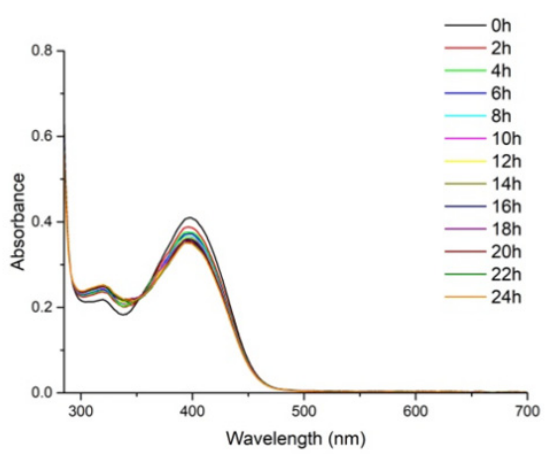

(b)

Figure 5. UV-Vis stability spectra in DMSO $\left(10^{-4} \mathrm{M}\right)$ for compounds $\mathbf{1}$ (a) and $\mathbf{2}$ (b). Spectra were recorded every $2 \mathrm{~h}$ for $24 \mathrm{~h}$.

\subsection{Catalytic Oxidations with Hydrogen Peroxide}

One of us discovered in 1993, a system for the efficient oxidation of various organic compounds with hydrogen peroxide, based on a simple vanadate ion compound. The obligatory component of this system was PCA (pyrazinecarboxylic acid). This reaction takes place at low temperatures in a solution of acetonitrile [85]. Further, this system was studied in detail, including the oxidation of alkanes, olefins, arenes, and alcohols with hydrogen peroxide and other oxidizing agents [86-88]. In the absence of a catalyst, the reaction proceeds extremely slowly, in five hours the yield of products is no more than $3-5 \%$ [89-92].

In this work, we present a study of the catalytic activity of 1-3 and the effect of 2pyrazinecarboxylic acid on the activities of these complexes. It turned out that all complexes exhibit high catalytic activity in the oxidation of alkanes, but only in the presence of PCA. The curves for the accumulation of oxidation products are shown in Figures 6-9.

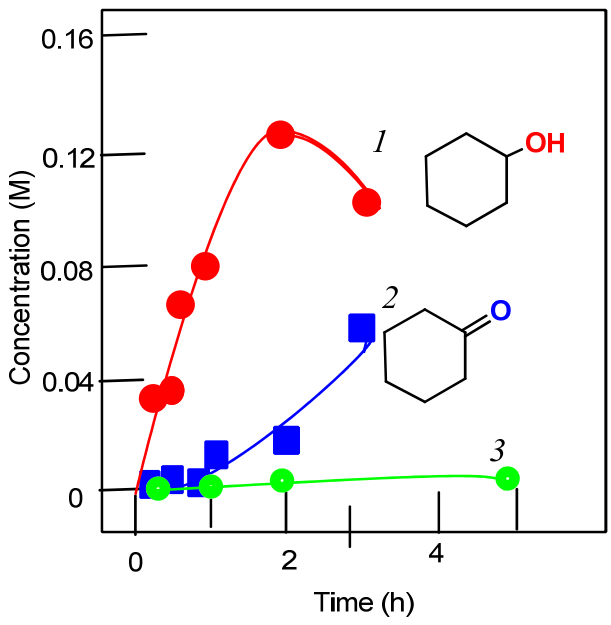

Figure 6. Oxidation of cyclohexane to cyclohexanol (curves 1 and 3) and cyclohexanone (curve 2) with hydrogen peroxide catalyzed by compound 1 in the presence of PCA (curves 1 and 2) and in the absence of PCA (curve 3). Conditions: cyclohexane (0.46 M); $\mathrm{H}_{2} \mathrm{O}_{2}(2.0 \mathrm{M}, 50 \%$ aqueous); complex $1\left(5 \times 10^{-4} \mathrm{M}\right)$; PCA $\left(2 \times 10^{-3} \mathrm{M}\right)$ in $\mathrm{MeCN}$ at $50^{\circ} \mathrm{C}$. Concentrations of cyclohexanone and cyclohexanol were measured after reduction of the aliquots with solid $\mathrm{PPh}_{3}$. 


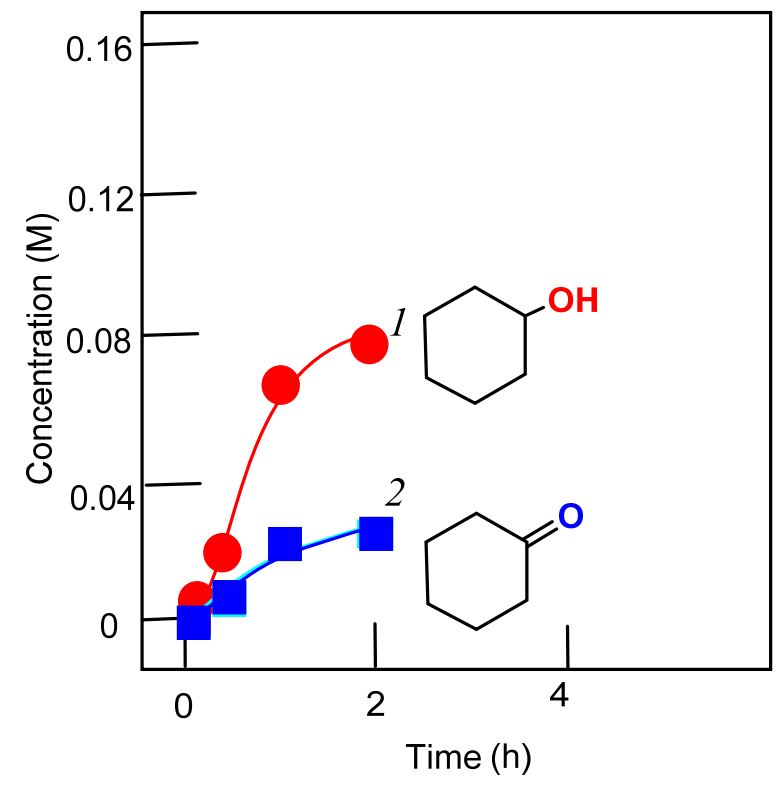

Figure 7. Oxidation of cyclohexane to cyclohexanol (curves 1) and cyclohexanone (curve 2) with hydrogen peroxide catalyzed by compound 1 in the presence of $\mathrm{HNO}_{3}$. Conditions: cyclohexane $(0.46 \mathrm{M}) ; \mathrm{H}_{2} \mathrm{O}_{2}\left(2.0 \mathrm{M}, 50 \%\right.$ aqueous); complex $1\left(5 \times 10^{-4} \mathrm{M}\right) ; \mathrm{HNO}_{3}(0.05 \mathrm{M})$ in $\mathrm{MeCN}$ at $50{ }^{\circ} \mathrm{C}$. Concentrations of cyclohexanone and cyclohexanol were measured after reduction of the aliquots with solid $\mathrm{PPh}_{3}$

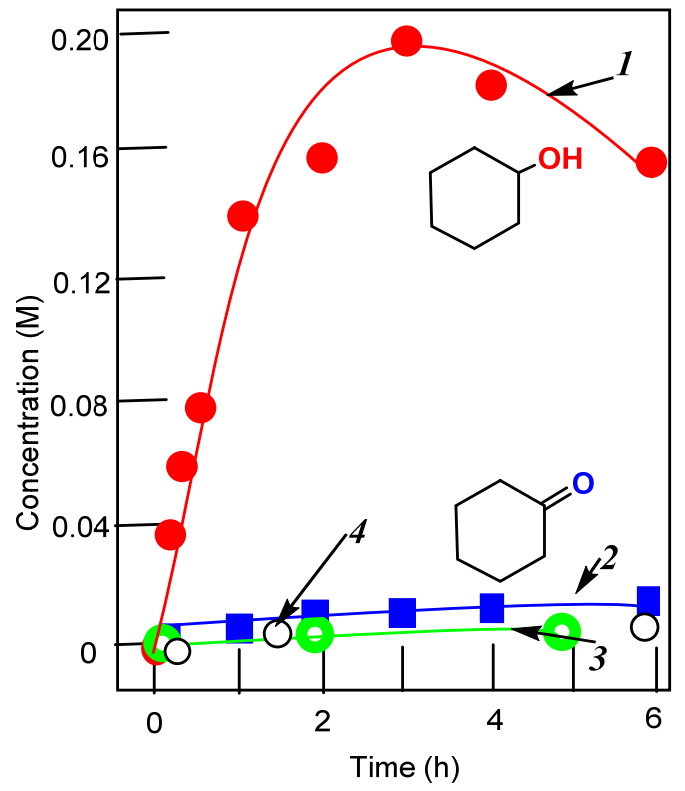

Figure 8. Oxidation of cyclohexane to cyclohexanol (curves 1 and 3) and cyclohexanone (curve 2) with hydrogen peroxide catalyzed by compound 2 in the presence of PCA (curves 1 and 2) and in the absence of PCA (curve 3); symbols marked by the number 4 show the reaction carried out in the absence of $\mathrm{PCA}$ and $\mathrm{HNO}_{3}$. Conditions: cyclohexane $(0.46 \mathrm{M}) ; \mathrm{H}_{2} \mathrm{O}_{2}(2.0 \mathrm{M}, 50 \%$ aqueous); complex $2\left(5 \times 10^{-4} \mathrm{M}\right)$; PCA $\left(2 \times 10^{-3} \mathrm{M}\right), \mathrm{HNO}_{3}(0.05 \mathrm{M})$ in $\mathrm{MeCN}$ at $50{ }^{\circ} \mathrm{C}$. Concentrations of cyclohexanone and cyclohexanol were measured after reduction of the aliquots with solid $\mathrm{PPh}_{3}$. 


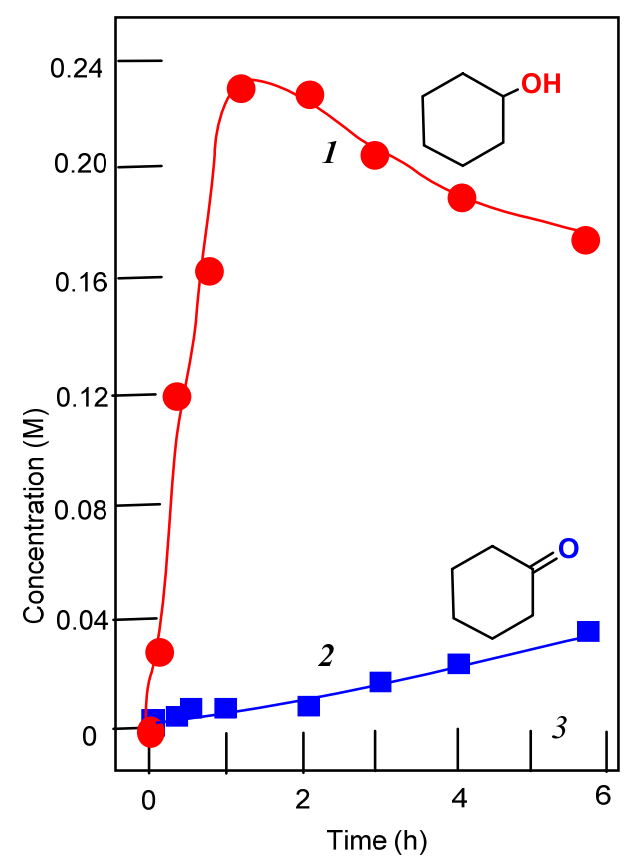

Figure 9. Accumulation of cyclohexanol (curve 1) and cyclohexanone (curve 2) in the oxidation of cyclohexane $(0.46 \mathrm{M})$ with hydrogen peroxide $(2.0 \mathrm{M}, 50 \%$ aqueous) catalyzed by compound 3 $\left(5 \times 10^{-4} \mathrm{M}\right)$; PCA $\left(2 \times 10^{-3} \mathrm{M}\right)$ in $\mathrm{MeCN}$ at $50^{\circ} \mathrm{C}$. Concentrations of cyclohexanone and cyclohexanol were measured after reduction of the aliquots with solid $\mathrm{PPh}_{3}$. The yield of cyclohexane oxidation products was $48 \%$.

In the case of using complexes 1-3, the yields of alkane oxidation products are noticeably higher than in reactions catalyzed by the vanadate anion-PCA system (Table S8). Compared to other vanadium complexes, that we and other researchers have used in the oxidative catalysis of alkanes and alcohols, we can say that the complexes described in this article exhibit a high activity. We have also studied the oxidation of cyclohexane in the presence of nitric acid. In this case, for complex 1 , the yield of oxidation products is much lower than in the reaction using PCA (see Figure 7). And in the case of complexes $\mathbf{2}$ and $\mathbf{3}$, the oxidation reactions of cyclohexane do not lead to any noticeable yields of oxidation products.

Consideration of the regio- and bond-selectivity in the oxidation of n-heptane and methylcyclohexane indicates that the oxidation proceeds with the participation of free hydroxyl radicals. The regio-selectivity parameters for the oxidation of n-heptane were obtained for complex 2: C (1):C (2):C (3):C (4) = 1.0:5.0:5.0:4.4. The bond-selectivity parameters for the oxidation of methylcyclohexane were also obtained: for complex $1: 1^{\circ}: 2^{\circ}: 3^{\circ}=1.0: 6.3: 16.7$; for complex $2: 1^{\circ}: 2^{\circ}: 3^{\circ}=1.0: 5.5: 15.0$; for complex $3: 1^{\circ}: 2^{\circ}: 3^{\circ}=1.0: 5.7: 16.0$, respectively. These values are close to the parameters obtained for oxidation reactions with the participation of hydroxyl radicals, although they are somewhat higher, apparently due to steric hindrances created by chelating ligands around the catalytic center in the molecules of our complexes [93].

The complexes show moderate activity in the oxidation of alcohols. The yields for the oxidation of phenylethanol to acetophenone with tert-butyl hydroperoxide under catalysis with complexes 1-3, were $46 \%, 23 \%$ and $32 \%$, respectively, at a temperature of $50{ }^{\circ} \mathrm{C}$, in acetonitrile for four hours. Hydrogen peroxide is much less productive in these reactions. In analogous oxidation reactions of cyclohexanol to cyclohexanone, corresponding yields were $10 \%, 5.5 \%$ and $5.5 \%$ after $5 \mathrm{~h}$. In the oxidation of cyclohexene, yields of cyclohexene1-ol were $10 \%, 6.5 \%$ and $5.5 \%$ correspondingly for complexes 1-3. Epoxide and other products of oxidation were formed in insignificant quantities. 


\subsection{Viability Studies}

HCT116 and A2780 cancer cell lines and normal dermal fibroblasts were used to evaluate the antiproliferative effect of complexes 1-3 (Figures 10 and S13 and Table 1).
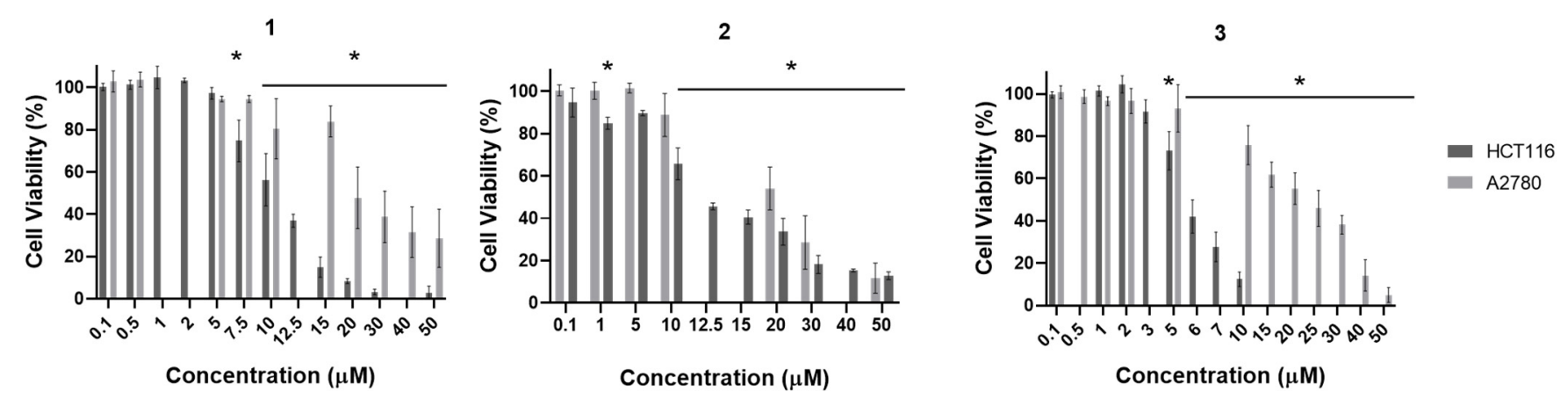

Figure 10. Antiproliferative effect of complexes 1-3 in the HCT116 and A2780 cancer cell lines, after 48 h, evaluated by the MTS method. Cell viabilities were normalized to DMSO 0.1\% $(v / v)$ (vehicle control). The results presented are mean \pm standard deviation of three independent assays. An asterisk indicates a $p$-value inferior to 0.05 .

Table 1. Relative $\mathrm{IC}_{50}$ values of complexes 1-3 in HCT116 and A2780 cancer cell lines and in normal dermal fibroblasts.

\begin{tabular}{cccc}
\hline Cell Lines & $\mathbf{1}(\boldsymbol{\mu M})$ & $\mathbf{2}(\boldsymbol{\mu M})$ & $\mathbf{3}(\boldsymbol{\mu M})$ \\
\hline HCT116 & $12.5 \pm 0.63$ & $9.6 \pm 0.54$ & $5.9 \pm 0.66$ \\
A2780 & $17.5 \pm 1.13$ & $20.7 \pm 3.11$ & $50.9 \pm 2.75$ \\
Fibroblasts & $15.8 \pm 1.49$ & $8.1 \pm 2.75$ & $14.5 \pm 2.33$ \\
\hline
\end{tabular}

Our results show that complex 1 displayed similar cytotoxicity in both cancer cell lines and in normal dermal fibroblasts (Figures 10 and S13 and Table 1). Complex 2 displayed a higher cytotoxicity in normal dermal fibroblasts compared to HCT116 and A2780 tumor cell lines (Figures 10 and S13 and Table 1). On the other hand, complex 3 showed a higher cytotoxicity in the HCT116 cell line $(5.9 \mu \mathrm{M})$ compared to normal dermal fibroblasts and the A2780 tumor cell line (Figures 11 and S13 and Table 1). Moreover, HCT116 was the cancer cell model more sensitive to the complexes (Figures 10 and S13 and Table 1). Interestingly, all complexes show a higher cytotoxicity (lower $\mathrm{IC}_{50}$ ) compared to cisplatin $\left(\mathrm{IC}_{50}\right.$ of $15 \mu \mathrm{M}$; see Supplementary Figure S13).
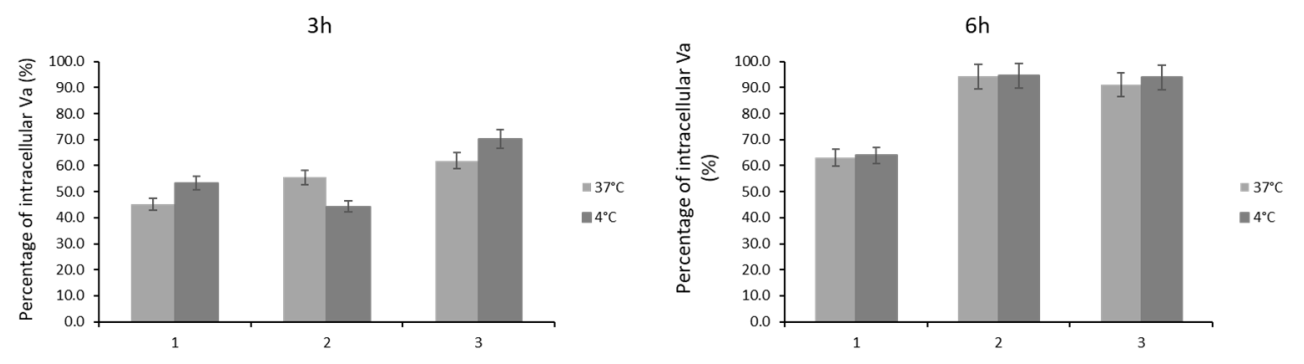

Figure 11. Internalization of complexes evaluated by the determination of the amount of vanadium (determined by ICP-AES) present in the cellular fraction of HCT116 after exposure of HCT116 cells to $20 \times \mathrm{IC}_{50}$ concentrations of complexes $1-3$ for 3 and $6 \mathrm{~h}$ at $4{ }^{\circ} \mathrm{C}$ and $37^{\circ} \mathrm{C}$. The results presented are mean \pm standard deviation of three independent assays.

The complexes herein described exhibit an $\mathrm{IC}_{50}$ in the range of 5.9 to $50.9 \mu \mathrm{M}$ in HCT116 and A2780 cancer cell lines (Figures 11 and S13 and Table 1). Previously published complexes bearing $\left[\mathrm{VO}(\mathrm{OMe})(\text { quin })_{2}\right]$ backbones, possess an $\mathrm{IC}_{50}$ between 0.96 and $10.09 \mu \mathrm{M}$ in HCT116 and A2780 cancer cell lines and from 11.24 to over $100 \mu \mathrm{M}$ in normal dermal fibroblasts [62]. This may be an indication that complexes bearing $\mathrm{VO}(2-\mathrm{Me}-\mathrm{Quin})$ 
backbones are not as promising for therapeutic use as previously described complexes bearing $\left[\mathrm{VO}(\mathrm{OMe})(\text { quin })_{2}\right]$ backbones [62]. Published results of the $\mathrm{IC}_{50}$ values of complexes bearing hydroxyquinoline derived ligands in cancer cell lines other than HCT116 and A2780 range from 0.9 to $219 \mu \mathrm{M}$, and oxovanadium and dioxidovanadium complexes present $\mathrm{IC}_{50}$ values between 0.96 to $224.5 \mu \mathrm{M}$, which indicates that the complexes here described have an $\mathrm{IC}_{50}$ in the lower end of the range (Table 1) [62,94,95].

To further understand the mechanisms of cytotoxicity associated with exposure to complexes 1-3, additional biological studies in the HCT116 cell line were carried out.

\subsection{Complex Internalization}

Internalization of the complexes was evaluated by exposing HCT116 cancer cells to $20 \times \mathrm{IC}_{50}$ concentrations of the complexes $1-3$ for 3 and $6 \mathrm{~h}$ at $4{ }^{\circ} \mathrm{C}$ and $37^{\circ} \mathrm{C}$ (Figure 11).

Our results show that temperature does induce statistically significant alterations in the amount of complex internalized, which suggests that there is no active transport of complexes into cells after 3 or $6 \mathrm{~h}$ (Figure 11), which has also been described in the literature with oxovanadium complexes [96]. After $6 \mathrm{~h}$ incubation, approximately $94 \%$ and $91 \%$ of complexes 2 and 3, respectively, and $60 \%$ of complex 1 were found in the HCT116 cellular fraction (Figure 11). These results suggest that the cytotoxicity might be directly correlated with the amount of internalized complex over time (Figures 10 and 11) and complexes 2 and 3 appear to be retained within HCT116 cells (Figure 11).

\subsection{Induction of Apoptosis in the HCT116 Cell Line Exposed to Complexes 1-3}

To understand if the loss of cellular viability induced by exposure to complexes 1-3 is associated with the triggering of programed cell death, HCT116 cells were exposed to the respective $\mathrm{IC}_{50}$ concentrations for $48 \mathrm{~h}$, and the Annexin V-Alexa fluor 488/PI dead cell apoptosis assay (ThermoFisher, Waltham, MA, USA) was used to determine the percentage of apoptotic cells (Figure 12).

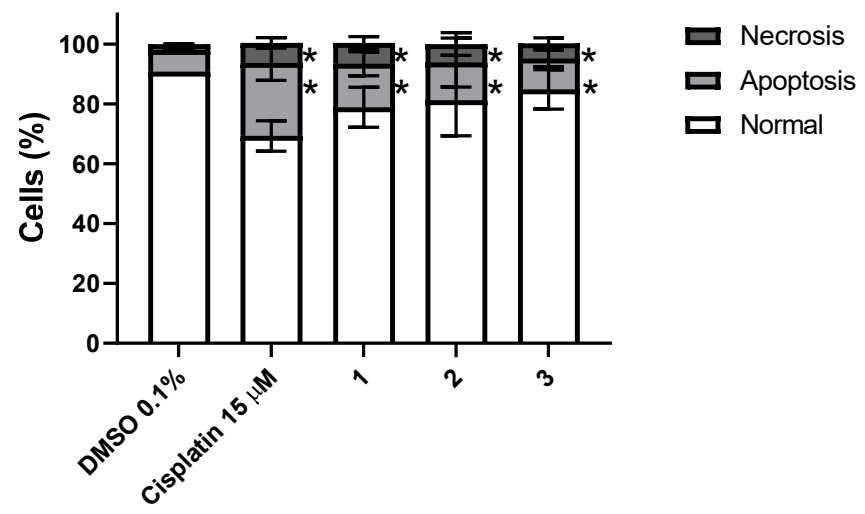

Figure 12. Apoptosis induction in the HCT116 cell line evaluated by flow cytometry after $48 \mathrm{~h}$ exposure to $\mathrm{IC}_{50}$ concentrations of complexes 1-3. DMSO $0.1 \%(v / v)$ was used as a negative control and Cisplatin $15 \mu \mathrm{M}$ was used as a positive control. The results presented are mean \pm standard deviation of three independent assays. An asterisk indicates a $p$-value inferior to 0.05 .

Our results show a statistically significant increase in the percentage of apoptotic cells due to exposure to complexes 1-3 (Figure 12). HCT116 cells displayed 14.5\%, 12.6\% and $10.4 \%$ of apoptotic cells after $48 \mathrm{~h}$ exposure to complexes 1-3, respectively, while the DMSO condition presented only $7.3 \%$ of apoptotic cells (Figure 12). There is also an increase in necrotic cells when compared with the DMSO control, which has $2 \%$ of necrotic cells, in cells exposed to complexes 1-3, of 7.0\%, $6.2 \%$ and $5.0 \%$, respectively. All complexes induced lower apoptotic cell death when compared with cisplatin (Figure 12). The induction of apoptosis has been reported for other vanadium complexes bearing 8-hydroxyquinolinebased ligands and dioxidovanadium(V) complexes [62,95]. Based on the viability data (Figures 10 and S13 and Table 1) and internalization data (Figure 11) we were expecting a 
higher cell death for complex 2 and particularly for complex 3 . Since we did not observe this trend, additional cell death mechanisms might be involved in the loss of cell viability. To further explain this issue, we assessed autophagic HCT116 cell death after exposure to complexes 1-3.

\subsection{Induction of Autophagy in the HCT116 Cell Line Exposed to Complexes 1-3}

Another mechanism of cell death triggered by exposure to metallic complexes is autophagy. The Autophagy Assay kit (Abcam) was used to determine the percentage of autophagic cells present after $48 \mathrm{~h}$ exposure to $\mathrm{IC}_{50}$ concentrations of complexes 1-3 (Figure 13).

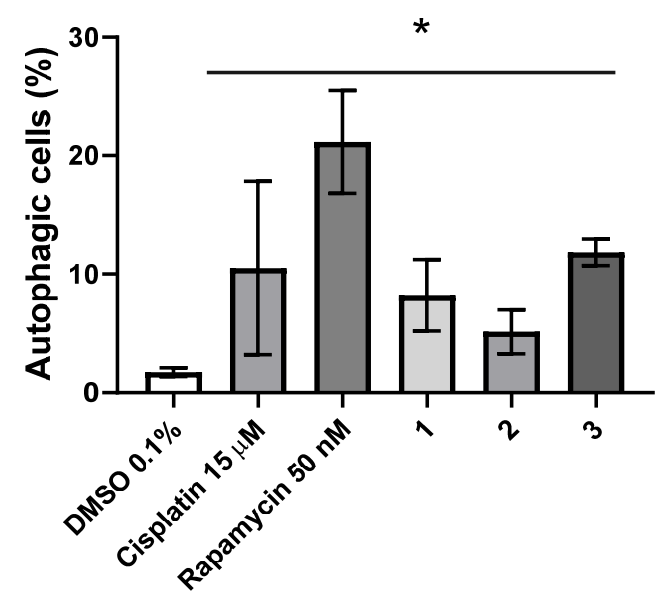

Figure 13. Autophagy induction in the HCT116 cell line evaluated by flow cytometry after 48 h exposure to $\mathrm{IC}_{50}$ concentrations of complexes $1-3$. DMSO $0.1 \%(v / v)$ was used as a negative control and Cisplatin $15 \mu \mathrm{M}$ and rapamycin $50 \mathrm{nM}$ were used as positive controls. The results presented are mean \pm standard deviation of three independent assays. An asterisk indicates a $p$-value inferior to 0.05 .

Exposure to complexes 1-3 led to a $7 \times, 4 \times$ and $10 \times$ increase of autophagic cells, respectively when compared to the DMSO control (Figure 13). Interestingly, complex 3 was able to induce more autophagic cell death compared to cisplatin (but to a lesser extent compared to rapamycin) (Figure 13). Therefore, induction of apoptosis and autophagy are responsible for the total loss of cell viability induced by the complexes in HCT116 cells (Figures 10, 11 and 13 and Table 1).

\subsection{Intracellular Reactive Oxygen Species (ROS) Production in the HCT116 Cell Line Exposed to Complexes 1-3}

ROS are known triggers of apoptosis and autophagy in cells exposed to metallic complexes. ROS production was evaluated in HCT116 cells exposed to $\mathrm{IC}_{50}$ concentrations of complexes 1-3 for $48 \mathrm{~h}$ (Figure 14).

Our results show a statistically significant increase of $3.3 \times$ and $2.3 \times$ of intracellular ROS in HCT116 cells exposed to complexes 2 and 3, respectively when compared to the DMSO control, although lower than cisplatin (Figure 14). Although not statistically significant, complex 1 also induces a 1.15× increase in the amount of intracellular ROS in HCT116 cells (Figure 14). 


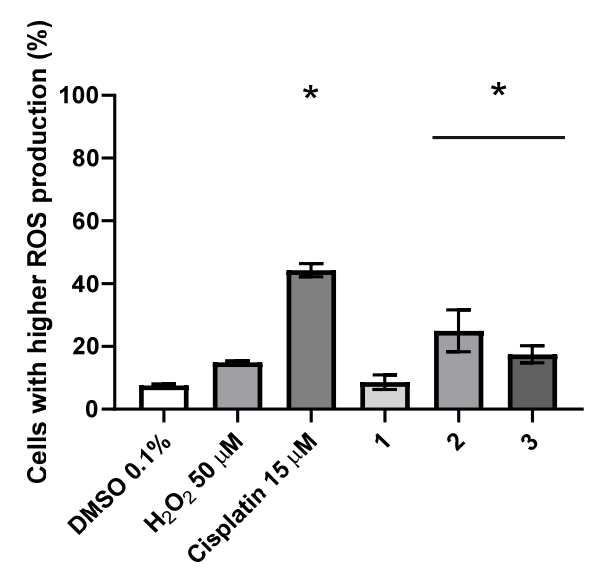

Figure 14. Intracellular ROS production in the HCT116 cell line after $48 \mathrm{~h}$ exposure to $\mathrm{IC}_{50}$ concentrations of complexes 1-3, evaluated by flow cytometry. DMSO $0.1 \%(v / v)$ was used as a negative control and Cisplatin $15 \mu \mathrm{M}$ and $\mathrm{H}_{2} \mathrm{O}_{2} 50 \mu \mathrm{M}$ were used as positive controls. The results presented are mean \pm standard deviation of three independent assays. An asterisk indicates a $p$-value inferior to 0.05 .

\subsection{Evaluation of Alterations in the Mitochondrial Membrane Potential of HCT116 Cells Exposed to Complexes 1-3}

To evaluate if the observed apoptosis induction in the HCT116 cell line is triggered by the intrinsic pathway, due to destabilization of mitochondria, changes in the mitochondrial membrane potential were evaluated using JC-1 dye (Abnova). This is a green fluorescent dye as a monomer; however, it will aggregate in the presence of a normal mitochondrial potential, which will cause a red-shift in emission spectra [97]. Measuring the green and red fluorescence by flow cytometry it is possible to calculate normalized ratios that can show us if there is an increase or decrease in the mitochondrial membrane potential (Figure 15).

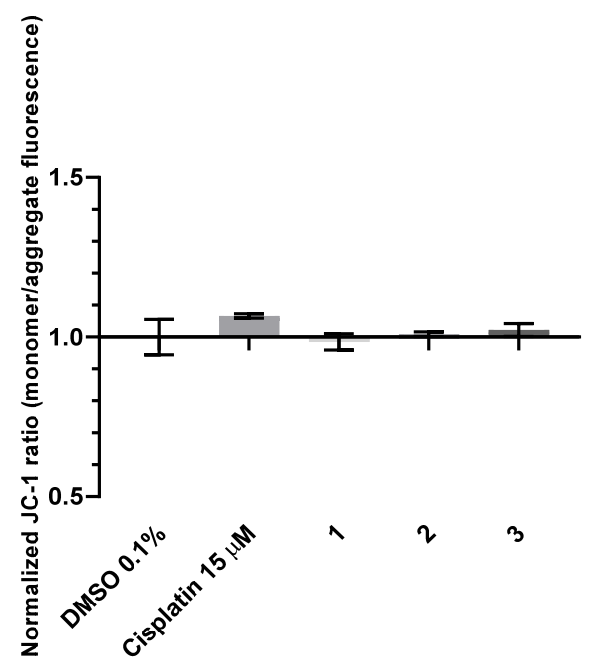

Figure 15. Alterations of the mitochondrial membrane potential in the HCT116 cell line after $48 \mathrm{~h}$ exposure to $\mathrm{IC}_{50}$ concentrations of complexes $1-3$, evaluated by flow cytometry. DMSO $0.1 \%(v / v)$ was used as a negative control and Cisplatin $15 \mu \mathrm{M}$ was used as a positive control. The results presented are mean \pm standard deviation of three independent assays.

Our results shown that there is no significant change of the mitochondrial membrane potential in HCT116 cells exposed to complexes 1-3 when compared with the DMSO control (Figure 15). The cisplatin control displays a small increase in the JC-1 (monomer/aggregate) ratio, which is indicative of mitochondrial membrane destabilization, although not statistically significant (Figure 15). 


\section{Materials and Methods}

3.1. Materials

2-methyl-8-hydroxyquinoline was commercially available (Sigma Aldrich, Darmstadt, Germany), while 2,5-dimethyl-8-hydroxyquinoline and 2,6-dimethyl-8-hydroxyquinoline were synthesized according to procedures described previously [98]. The analytical data (FT-IR and HR-MS spectra, X-ray analysis and PXRD spectrum) for [VO(2-Me-quin) 2 ] (3) provided a good agreement with those reported in reference [64].

\subsection{Synthesis of $\left[V O\left(2,6-(\mathrm{Me})_{2}-q u i n\right)_{2}\right](\mathbf{1})$ and $\left[V O\left(2,5-(\mathrm{Me})_{2}-q u i n\right)_{2}\right]$ (2)}

A mixture of $\mathrm{VO}(\mathrm{acac})_{2}(1 \mathrm{mmol}, 0.26 \mathrm{~g})$ and the appropriate 2,5-dimethyl-8-hydroxyq uinoline or 2,6-dimethyl-8-hydroxyquinoline ( $2 \mathrm{mmol} ; 0.35 \mathrm{~g}$ ) was suspended in toluene $(30 \mathrm{~mL})$, and the resulting solution was refluxed for $2 \mathrm{~h}$ in open air. After several days the crystalline solid of the vanadium(IV) complex was collected. The crystals suitable for $\mathrm{X}$-ray analysis were obtained by recrystallization from an acetonitrile/chloroform mixture $(1 / 1 v / v)$.

[VO(2,6-(Me) $)_{2}$-quin) $)_{2}$ (1): Yield 55\%. HR-MS (ESI): calcd for $\mathrm{C}_{22} \mathrm{H}_{20} \mathrm{~N}_{2} \mathrm{O}_{3} \mathrm{NaV}^{+}$ $[\mathrm{M}+\mathrm{Na}]^{+}$434.0811, found 434.0818. Anal. Calc. for $\mathrm{C}_{22} \mathrm{H}_{20} \mathrm{~N}_{2} \mathrm{O}_{3} \mathrm{~V}(411.34 \mathrm{~g} / \mathrm{mol})$ : C 64.25, H 4.90, N 6.81\%. Found: C 64.55, H 4.73, N 6.78\%. IR (KBr, $\left.\mathrm{cm}^{-1}\right)$ : 3436(s), 3028(w), 2920(m), 1613(w), 1575(s), 1496(s), 1469(m), 1439(w), 1401(s), 1377(w), 1346(m), 1266(s), 1208(w), 1041(s), 1132(s), 1033(w), 987(m), $976(\mathrm{~m}), 946(\mathrm{~s}), 847(\mathrm{~m}), 789(\mathrm{w}), 782(\mathrm{w})$, 725(m), 686(m), 653(m), 634(m), 618(w), 600(w), 533(m), 432(w). UV-Vis (DMSO, $\lambda_{\max }, \mathrm{nm}$ $\left.\left(\varepsilon, \mathrm{dm}^{3} \cdot \mathrm{mol}^{-1} \cdot \mathrm{cm}^{-1}\right)\right): 268$ (25170), 312 (1930), 380 (2310), 523 (530), 585 (280), 701 (110).

[VO(2,5-(Me) $)_{2}$-quin) $)_{2}$ (2): Yield 75\%. HRMS (ESI): calcd for $\mathrm{C}_{22} \mathrm{H}_{20} \mathrm{~N}_{2} \mathrm{O}_{3} \mathrm{NaV}^{+}[\mathrm{M}$ $+\mathrm{Na}^{+}$434.0811, found 434.0813. Anal. Calc. for $\mathrm{C}_{22} \mathrm{H}_{20} \mathrm{~N}_{2} \mathrm{O}_{3} \mathrm{~V}(411.34 \mathrm{~g} / \mathrm{mol}): \mathrm{C}$ 64.25, H 4.90, N 6.81\%. Found: C 63.94, H 4.69, N 6.52\%. IR (KBr, $\left.\mathrm{cm}^{-1}\right): 3438(\mathrm{~m})$, 3028(m), 2892(w), 2861(w), 1597(m), 1571(s), 1515(s), 1462(s), 1434(s), 1409(m), 1374(m), 1314(s), 1291(m), 1263(s), 1245(m), 1223(w), 1157(m), 1093(s), 983(s), 947(w), 836(s), 819(w), 787(m), 767(s), 747(m), 644(m), 632(m), 523(m), 501(w), 452(w). UV-Vis (DMSO, $\lambda_{\max }, \mathrm{nm}$ $\left.\left(\varepsilon, \mathrm{dm}^{3} \cdot \mathrm{mol}^{-1} \cdot \mathrm{cm}^{-1}\right)\right): 320(3960), 398(6600), 582(100), 753(80)$.

\subsection{X-ray Crystal Structure Determination}

The X-ray diffraction data for complexes $\mathbf{1}$ and $\mathbf{2}$ were collected using an Oxford Diffraction four-circle diffractometer Gemini A Ultra with an Atlas CCD detector using graphite monochromated $\mathrm{MoK} \alpha$ radiation $(\lambda=0.71073 \AA)$ at room temperature. Diffraction data collection, cell refinement and data reduction were performed using the CrysAlis ${ }^{\text {Pro }}$ software [99]. The structures were solved by direct methods using SHELXS and refined by full-matrix least-squares on $F^{2}$ using SHELXL-2014 [100]. All the non-hydrogen atoms were refined anisotropically, and hydrogen atoms were placed in calculated positions and refined with riding constraints: $d(\mathrm{C}-\mathrm{H})=0.93 \AA, U_{\mathrm{iso}}(\mathrm{H})=1.2 U_{\mathrm{eq}}(\mathrm{C})$ (for aromatic) and $d(\mathrm{C}-\mathrm{H})=0.96 \AA, U_{\mathrm{iso}}(\mathrm{H})=1.5 U_{\mathrm{eq}}(\mathrm{C})$ (for methyl). The methyl groups were allowed to rotate about their local threefold axis. Details of the crystallographic data collection, structural determination, and refinement for $\mathbf{1}$ and $\mathbf{2}$ are given in Table 2, whereas selected bond lengths and angles for them are listed in Tables S1 and S2, Supplementary Materials.

Powder X-ray diffraction (XRPD) measurements on $\mathbf{1}$ and $\mathbf{2}$ were performed on a PANalytical Empyrean $X$-ray diffractometer by using $\mathrm{Cu}-\mathrm{K}_{\alpha}$ radiation $(\lambda=1.5418 \AA)$, in which the $\mathrm{X}$-ray tube was operated at $40 \mathrm{kV}$ and $30 \mathrm{~mA}$ ranging from 5 to $50^{\circ}$ (Figures 2 and S9).

\subsection{Physical Measurements}

IR spectra were recorded on a Nicolet iS5 FT-IR spectrophotometer in the spectral range $4000-400 \mathrm{~cm}^{-1}$ with the samples in the form of KBr pellets (Figure S1, Supplementary Materials). HRMS analysis (Figure S2, Supplementary Materials) was performed on a Waters Xevo G2 Q-TOF mass spectrometer (Waters Corporation, Milford, MA, USA) with an ESI ion source. Full-scan MS data were collected from 100 to $1000 \mathrm{Da}$ in positive ion mode with a scan time of $0.5 \mathrm{~s}$. To ensure accurate mass measurements, data were collected 
in centroid mode and mass was corrected during acquisition using a leucine enkephalin solution as an external reference (Lock-Spray ${ }^{\mathrm{TM}}$ ), with the reference ion at $m / z 556.2771 \mathrm{Da}$ $\left([\mathrm{M}+\mathrm{H}]^{+}\right)$. Elemental analyses $(\mathrm{C}, \mathrm{H}, \mathrm{N})$ were performed on a Perkin-Elemer $\mathrm{CHN}-2400$ analyzer. The electronic spectra were obtained using Nicolet Evolution 220 in the range 240-1000 nm in DMSO (Figure S10, Supplementary Materials).

Table 2. Crystal data and structure refinement for 1-2.

\begin{tabular}{|c|c|c|}
\hline & 1 & 2 \\
\hline Empirical formula & $\mathrm{C}_{22} \mathrm{H}_{20} \mathrm{~N}_{2} \mathrm{O}_{3} \mathrm{~V}$ & $\mathrm{C}_{22} \mathrm{H}_{20} \mathrm{~N}_{2} \mathrm{O}_{3} \mathrm{~V}$ \\
\hline Formula weight & 411.34 & 411.34 \\
\hline$T, \mathrm{~K}$ & 295.0(2) & $295.0(2)$ \\
\hline Wavelength, $\AA$ & 0.71073 & 0.71073 \\
\hline Crystal system & Monoclinic & Monoclinic \\
\hline Space group & $\mathrm{C} 2 / \mathrm{c}$ & $P 2_{1} / c$ \\
\hline \multicolumn{3}{|l|}{ Unit cell dimensions, $\AA$ and ${ }^{\circ}$} \\
\hline$a$ & 18.8566(15) & $15.6046(11)$ \\
\hline$b$ & $8.2237(4)$ & $8.1475(5)$ \\
\hline$c$ & 13.2105(8) & $16.5949(16)$ \\
\hline$\beta$ & $113.906(5)$ & $117.340(11)$ \\
\hline$V, \AA^{3}$ & $1872.8(2)$ & $1874.2(3)$ \\
\hline Z & 4 & 4 \\
\hline$D_{c}, \mathrm{~g} \mathrm{~cm}^{-3}$ & 1.459 & 1.458 \\
\hline Absorption coefficient, $\mathrm{mm}^{-1}$ & 0.556 & 0.555 \\
\hline$F(000)$ & 852 & 852 \\
\hline Crystal size, $\mathrm{mm}$ & $0.283 \times 0.137 \times 0.055$ & $0.162 \times 0.089 \times 0.079$ \\
\hline$\theta$ range for data collection ${ }^{\circ}$ & 3.46 to 25.05 & 3.49 to 25.05 \\
\hline \multirow{3}{*}{ Index ranges } & $-22 \leq h \leq 22$ & $-18 \leq h \leq 17$ \\
\hline & $-9 \leq k \leq 9$ & $-8 \leq k \leq 9$ \\
\hline & $-15 \leq l \leq 15$ & $-19 \leq l \leq 18$ \\
\hline Reflections collected & $\overline{6154}$ & $\overline{7065}$ \\
\hline Independent reflections & $1653\left[R_{\mathrm{int}}=0.0221\right]$ & $3291\left[R_{\mathrm{int}}=0.0479\right]$ \\
\hline Completeness to $2 \theta$ & 99.7 & 99.3 \\
\hline Min. and max. transm. & 0.712 and 1.000 & 0.588 and 1.000 \\
\hline Data/restraints/parameters & $1653 / 0 / 130$ & $3291 / 0 / 257$ \\
\hline Goodness-of-fit on $F^{2}$ & 1.086 & 1.002 \\
\hline Final $R$ indices $[I>2 \sigma(I)]$ & 0.0326 & 0.0489 \\
\hline $\begin{array}{c}R 1 \\
w R 2\end{array}$ & 0.0931 & 0.1065 \\
\hline$R$ indices (all data) & & \\
\hline$R 1$ & 0.0355 & 0.0834 \\
\hline$w R 2$ & 0.0950 & 0.1202 \\
\hline Largest diff. peak and hole, e $\AA^{-3}$ & 0.50 and -0.24 & 0.34 and -0.32 \\
\hline CCDC number & 1971585 & 1971586 \\
\hline
\end{tabular}

\subsection{EPR Spectroscopy}

Electron paramagnetic resonance (EPR) spectra of the oxidovanadium(IV) complexes were measured using a Bruker ELEXYS E 500 operating at the X-band frequency $(9.7 \mathrm{GHz})$. The solid compounds $\mathbf{1}$ and $\mathbf{2}$ dissolved in water and a few drops of DMSO, were added to the samples to ensure good glass formation at liquid nitrogen temperature [101]. A microwave frequency of $6.231 \mathrm{GHz}$, power of $10 \mathrm{~mW}$ and modulation amplitude of $8 \mathrm{G}$ was used. Anisotropic spectra were recorded on frozen solutions at $77 \mathrm{~K}$ using quartz Dewar and glass capillary tubes at room temperature. An analysis of the EPR spectra was carried out using the WinEPR SimFonia software package, version 1.26b [102]. 


\subsection{Biological Assays}

\subsubsection{Cell Culture}

The human colorectal carcinoma derived cancer cell line (HCT116) and human normal dermal fibroblasts (Ref. PCS-201-010) were purchased from American Type Culture Collection (ATCC, Manassas, VA, USA) and grown in Dulbecco's modified Eagle medium (DMEM). The human ovarian carcinoma derived cancer cell line (A2780) was purchased from Merck (Darmstadt, Germany) and cultivated in Roswell Park Memorial Institute (RPMI) 1640 culture medium. All media were supplemented with $10 \%$ fetal bovine serum and a $1 \%$ Pen/Strep solution (all media and supplements were from Thermo Fischer Scientific, Waltham, MA, USA). Cell cultures were maintained at $37^{\circ} \mathrm{C}$, in a humified atmosphere of $5 \%(v / v) \mathrm{CO}_{2}[103,104]$.

\subsubsection{Viability Assays}

Normal dermal fibroblasts and cancer cell lines HCT116 and A2780 were seeded in 96well plates with a density of 7500 cells per well. After $24 \mathrm{~h}$, culture media was replaced, and cells were exposed to different concentrations of complexes 1-3 or DMSO $0.1 \%(v / v)$ (vehicle control) or cisplatin (positive control) for $48 \mathrm{~h}$ (Figure S14). Cells exposed to cisplatin were used as a positive control $[103,104]$. After $48 \mathrm{~h}$ of incubation, the CellTiter $96^{\circledR}$ Aqueous Non-Radioactive Proliferation assay (Promega, Madison, WI, USA) was used to determine cellular viability through the production of formazan through the reduction of 3-(4,5dimethylthiazol-2-yl)-5-(3-carboxymethoxyphenyl)-2-(4-sulfophenyl)-2H-tetrazolium, inner salt (MTS) by dehydrogenases present in metabolically active cells $[103,104]$. The amount of formazan can be determined by its absorbance at $492 \mathrm{~nm}$ in an Infinite M200 microplate reader (Tecan, Mannedorf, Switzerland) [103,104]. The biological activity of the complexes was compared using the half maximal inhibitory concentration of cellular proliferation $\left(\mathrm{IC}_{50}\right)$ determined with Prism 8.2.1 software for windows (GraphPad Software, La Jolla, CA, USA).

\subsubsection{Vanadium Detection in the HCT116 Cell Line by ICP-AES}

The internalization of the vanadium complexes in HCT116 cells was evaluated by an inductive plasma atomic emission spectrometry technique (ICP-AES). HCT116 cells were seeded in $25 \mathrm{~cm}^{2}$ culture flasks with a cellular density of $1 \times 10^{5}$ cells per mL. After $24 \mathrm{~h}$ of incubation at $37^{\circ} \mathrm{C}$ in a humified atmosphere of $5 \%(v / v) \mathrm{CO}_{2}$, the culture medium was replaced with fresh culture medium containing a $20 \times \mathrm{IC}_{50}$ at $48 \mathrm{~h}$ concentration of the complexes 1-3 or $0.1 \%(v / v)$ of DMSO (vehicle control) followed by incubations of $3 \mathrm{~h}$ or $6 \mathrm{~h}$ at 37 or $4{ }^{\circ} \mathrm{C}$. We used this concentration to ensure that we were above the detection limit of the technique. This concentration $\left(20 \times \mathrm{IC}_{50}\right)$ does not induce a loss of cell viability for the selected time points. The culture medium was then collected, and cells detached with trypsin and centrifuged at $700 \times g$ for 5 min at $15^{\circ} \mathrm{C}$. The supernatant (culture medium plus trypsin) and the pellet (cells) were stored separately at $-20^{\circ} \mathrm{C}$ until freshly made aqua regia was added to all the samples as previously described [104]. The vanadium quantification in each fraction was performed by ICP-AES, as a paid service.

\subsubsection{Evaluation of Apoptosis Induction in the HCT116 Cell Line by Flow Cytometry}

Apoptosis induction in HCT116 cells was evaluated using the Annexin V-Alexa fluor 488/PI dead cell apoptosis assay (Thermo Fischer Scientific). Briefly, HCT116 cells were seeded in 6-well plates $\left(2 \times 10^{5}\right.$ cells per well) and then incubated $48 \mathrm{~h}$ with the $\mathrm{IC}_{50}$ concentrations of complexes 1-3 at $37^{\circ} \mathrm{C}$ in a humified atmosphere of $5 \%(v / v) \mathrm{CO}_{2}$. Cells were also incubated with DMSO 0.1\% (vehicle control) and cisplatin $15 \mu \mathrm{M}$ (positive control). Following the manufacturer's instructions, after this incubation period, cells were detached with trypsin, washed with PBS $1 \times$ and incubated $15 \mathrm{~min}$ at room temperature with Annexin V-Alexa fluor 488 assay solution and $10 \mu \mathrm{g} \mathrm{mL}-1$ propidium iodide $[97,104]$. An Attune acoustic focusing cytometer (ThermoFisher Scientific, Waltham, MA, USA) was 
used to analyze cells and the resulting information was processed with the respective Attune Cytometric Software 2.1 (ThermoFisher Scientific, Waltham, MA, USA).

\subsubsection{Autophagy Induction Evaluation in the HCT116 Cell Line by Flow Cytometry}

Autophagy induction in HCT116 cells was evaluated using the Autophagy Assay kit (Abcam), according to the manufacturer's instructions. HCT116 cells were seeded in 6-well plates at a cellular density of $2 \times 10^{5}$ cells per well. After $24 \mathrm{~h}$, cells were incubated with the $\mathrm{IC}_{50}$ concentrations of complexes 1-3 for $48 \mathrm{~h}$ at $37^{\circ} \mathrm{C}$ in a humified atmosphere of $\left.5 \% \mathrm{v} / \mathrm{v}\right)$ $\mathrm{CO}_{2}$. In addition to the DMSO $0.1 \% v / v$ vehicle control, cisplatin $15 \mu \mathrm{M}$ and rapamycin $0.5 \mu \mathrm{M}$ were performed as positive controls. After $48 \mathrm{~h}$ of incubation, cells were detached from the wells with trypsin and washed with Assay Buffer $1 \times$ before being incubated $30 \mathrm{~min}$ at $37^{\circ} \mathrm{C}$ in DMEM medium with the Green Stain solution. Cells were then washed and resuspended in Assay Buffer $1 \times$ and this was followed by analysis in an Attune acoustic focusing cytometer (ThermoFisher Scientific), and the results were analyzed with the respective instrument software (Attune Cytometric Software, version 2.1).

3.6.6. Intracellular Reactive Oxygen Species (ROS) Production Evaluation in the HCT116 Cell Line by Flow Cytometry

The induction of ROS in HCT116 cells was evaluated indirectly by flow cytometry using a specific dye, $2^{\prime}, 7^{\prime}$-dichlorodihydrofluorescein diacetate $\left(\mathrm{H}_{2} \mathrm{DCF}-\mathrm{DA}\right)$ (Thermo Fischer Scientific). In the presence of ROS, intracellular esterases remove the acetate groups of the dye which leads to an increased fluorescence $[97,104]$. HCT116 cells were seeded in 6-well plates $\left(4 \times 10^{5}\right.$ cells per well) for the initial $24 \mathrm{~h}$ of incubation. Cells were incubated with DMSO $0.1 \%(v / v)$ (vehicle control), $50 \mu \mathrm{M} \mathrm{H}_{2} \mathrm{O}_{2}$ and $15 \mu \mathrm{M}$ cisplatin (positives controls) and the complexes 1-3 at their $\mathrm{IC}_{50}$ concentrations for $48 \mathrm{~h}$ at $37^{\circ} \mathrm{C}$ in a humified atmosphere of $5 \%(v / v) \mathrm{CO}_{2}$. Cells were then detached from the wells with trypsin and washed with PBS $1 \times$ before incubation with $100 \mu \mathrm{M}$ of $\mathrm{H}_{2}$ DCF-DA for $20 \mathrm{~min}$ at $37^{\circ} \mathrm{C}$, then processed in an Attune acoustic focusing cytometer (ThermoFisher Scientific), with the resulting data analyzed using the respective software (Attune Cytometric Software, version 2.1).

3.6.7. Mitochondrial Membrane Potential Evaluation in the HCT116 Cell Line by Flow Cytometry

The mitochondrial membrane potential in HCT116 cells was evaluated using 5, $5^{\prime}, 6,6^{\prime}$ Tetrachloro-1,1',3,3'-tetraethylbenzimidazolocarbocyanine iodide, JC-1 (Abnova Corporation, Walnut, CA, USA). The mitochondrial potential is an important parameter of mitochondrial function, and is thus used as an indicator of cell health. In healthy cells with high potential, JC-1 shows aggregates with intense red fluorescence. On the other hand, in cells with low mitochondrial membrane potential (for example cells in apoptosis), JC-1 remains in the monomeric form, which exhibits green fluorescence ${ }^{104}$ [105]. Briefly, HCT116 cells were seeded in 6-well plates at a cellular density of $2 \times 10^{5}$ cells per well and then incubated $48 \mathrm{~h}$ with the $\mathrm{IC}_{50}$ concentrations of vanadium complexes 1-3 at $37^{\circ} \mathrm{C}$ in a humified atmosphere of $5 \%(v / v) \mathrm{CO}_{2}$, having as controls DMSO $0.1 \%$ (vehicle control), cisplatin $15 \mu \mathrm{M}$ and doxorubicin $0.4 \mu \mathrm{M}$ (positive controls). Afterwards cells were detached with trypsin, washed with PBS $1 \times$ and incubated 20 min at $37^{\circ} \mathrm{C}$ in DMEM medium with the JC-1 solution. Cells were again washed and resuspend in DMEM medium without phenol red and analyzed in an Attune acoustic focusing cytometer (ThermoFisher Scientific).

\subsection{Catalytic Studies}

The total volume of the reaction solution was $5 \mathrm{~mL}$ (Caution: the combination of air or molecular oxygen and $\mathrm{H}_{2} \mathrm{O}_{2}$ with organic compounds at elevated temperatures may be explosive!). Cylindrical glass vessels with vigorous stirring of the reaction mixture were used for the oxidation of alkanes with hydrogen peroxide which were typically carried out in air in a thermostated solution. Initially, a portion of $50 \%$ aqueous solution of 
hydrogen peroxide was added to the solution of the catalyst and substrate in acetonitrile. The aliquots of the reaction solution were analyzed by GC (a 3700 instrument, fused silica capillary column FFAP/OV-101 20/80 w/w, $30 \mathrm{~m} \times 0.2 \mathrm{~mm} \times 0.3 \mu \mathrm{m}$; argon as a carrier gas. Attribution of peaks was made by comparison with chromatograms of authentic samples). Usually samples were analyzed twice, i.e., before and after the addition portion by portion of the excess of solid $\mathrm{PPh}_{3}$. This method was proposed and used by one of us previously [106,107].

Alkyl hydroperoxides are transformed in the GC injector into a mixture of the corresponding ketone and alcohol. Due to this, we quantitatively reduced the reaction samples with $\mathrm{PPh}_{3}$ to obtain the corresponding alcohol. This method allows us to calculate the real concentrations not only of the hydroperoxide, but of the alcohols and ketones present in the solution at a given moment. An example is shown in Figure 16.
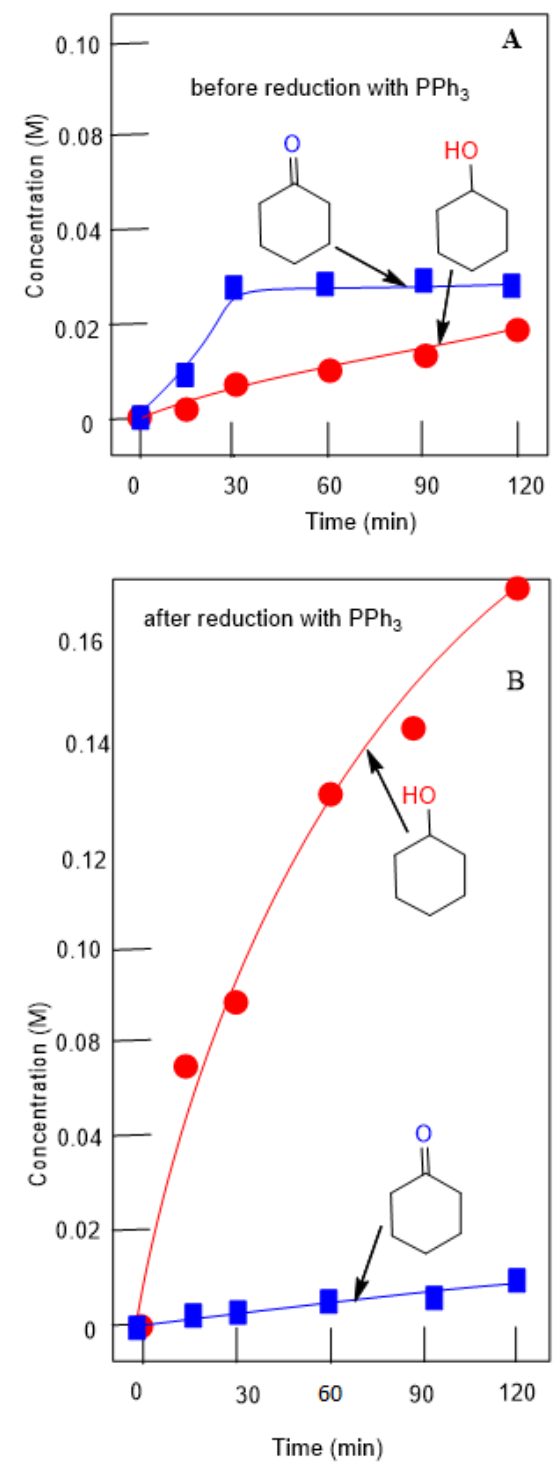

Figure 16. Accumulation of cyclohexanol and cyclohexanone in the oxidation of cyclohexane $(0.46 \mathrm{M})$ with $\mathrm{H}_{2} \mathrm{O}_{2}(2.0 \mathrm{M})$ catalyzed by complex $2\left(5 \times 10^{-4} \mathrm{M}\right)$ at $50{ }^{\circ} \mathrm{C}$ in acetonitrile. Concentrations of products were measured by GC before (Graph (A)) and after (Graph (B)) the reduction of the reaction samples with solid $\mathrm{PPh}_{3}$. 


\section{Conclusions}

The studies revealed that methyl-functionalization of 8-hydroxyquinoline facilitates the formation of five-coordinated oxidovanadium(IV) complexes in the reaction of bis(acety lacetonato)oxidovanadium(IV) 2,6-(Me) ${ }_{2}$-quin, 2,5-(Me) ${ }_{2}$-quin and 2-Me-quin.

Complexes 1-3 catalyze very efficient transformation of saturated hydrocarbons into alkyl hydroperoxides, alcohols and ketones. The reaction requires addition of PCA and occurs with the participation of hydroxyl radicals.

Here we show that complex 3 effectively reduced the viability of a HCT116 colorectal cancer cell line with low or no cytotoxicity in normal dermal fibroblasts or in an ovarian carcinoma cell line, respectively. On the other hand, complexes 1 and 2 bearing additional methyl groups show lower antiproliferative activities in HCT116 cells, and complex 2 shows some degree of cytotoxicity towards primary fibroblasts. Complexes internationalization is probably associated with passive transport, with more than $90 \%$ of complexes $\mathbf{2}$ and 3 being in the cellular fraction after a $6 \mathrm{~h}$ incubation. All complexes can increase in the production of intracellular ROS which can trigger apoptosis and autophagy in the HCT116 cell line. Mitochondrial membrane potential was not significantly altered by the three complexes in HCT116 cells which may indicate that the intrinsic pathway is not activated.

Supplementary Materials: The following are available online. Figure S1: IR spectra of complexes 1-3 and free ligands, Figure S2: HRMS of complexes 1-3, Tables S1-S3: Selected bond lengths and angles for 1-3, Table S4: Short intra- and intermolecular hydrogen bonds, Table S5: Short $\pi \bullet \bullet \bullet \pi$ interactions, Table S6: $\mathrm{X}-\mathrm{Y} \bullet \bullet \mathrm{Cg}(\mathrm{J})(\pi$-ring) interactions, Figures S3-S5: Hirshfeld surface and 2D fingerprint plot for 1-3, together with the relative contributions of various intermolecular interactions with the Hirshfeld surface, Figures S6-S8: View of the intermolecular interactions and packing in 1-3, Table S7: The selected structural parameters of five-coordinated vanadium(IV) complexes, Figure S9: X-ray powder diffraction patterns of 1-3, Figure S10: EPR frozen solution spectra (at $77 \mathrm{~K}$ ) in acetonitrile, Figure S11: UV-Vis spectra of complexes 1-3, Figure S12: UV-Vis stability spectra in DMSO of 1-3, Figure S13: Antiproliferative effect of complexes 1-3 in normal dermal fibroblasts, after 48 h, evaluated by the MTS method, Figure S14: Cell viability of HCT116 cells.

Author Contributions: Synthesis of V(IV) complexes, J.P.-G., K.C. and B.M.; general characterization, X-ray analysis and UV-Vis studies, J.P.-G., K.C. and B.M.; synthesis of 2,5-dimethyl-8hydroxyquinoline and 2,6-dimethyl-8-hydroxyquinoline, J.E.N.; HRMS analysis, K.E.; EPR studies, A.B. and A.L.(Agnieszka Lewińska); studies of catalytic oxidations, L.S.S., N.S.I. and G.B.S.; biological data assessment, A.L.(André Luz) and L.R.R.; interpretation and writing of initial and final version of the manuscript, A.R.F. and P.V.B. All authors have read and agreed to the published version of the manuscript.

Funding: This research was funded by the Russian Foundation for Basic Research (Grant Nos. 19-0300142), the Ministry of Education and Science of the Russian Federation (project code RFMEFI61917X0007), as well as by the Initiative Program in the frames of the State Task 0082-2014-0007, "Fundamental regularities of heterogeneous and homogeneous catalysis" and also by the Program of Fundamental Research of the Russian Academy of Sciences for 2013-2020 on the research issue of IChP RAS No. 47.16. State registration number of the Center of Information Technologies and Systems for Executive Power Authorities (CITIS): AAAA-A17-117040610283-3; GC analysis was performed with the financial support from the Ministry of Education and Science of the Russian Federation using the equipment of the Center for molecular composition studies of the A.N. Nesmeyanov INEOS RAS. This work is also financed by national funds from FCT-Fundação para a Ciência e a Technological, I.P., in the scope of the project UIDP/04378/2020 and UIDB/04378/2020 of the Research Unit on Applied Molecular Biosciences-UCIBIO and the project LA/P/0140/2020 of the Associate Laboratory Institute for Health and Bioeconomy-i4HB.

Institutional Review Board Statement: Not applicable.

Informed Consent Statement: Not applicable.

Data Availability Statement: Crystallographic data for $\mathbf{1}$ and $\mathbf{2}$ have been deposited with the Cambridge Crystallographic Data Center, CCDC 1971585-1971586. Copies of this information may be 
obtained free of charge from the Director, CCDC, 12 Union Road, Cambridge CB2 1EZ, UK (Fax: +44-1223-336033; e-mail: deposit@ccdc.cam.ac.uk or www.ccdc.cam.ac.uk, 12 December 2019).

Acknowledgments: Authors are thankful for support by RFBR according to Research Project Grant No. 19-03-00142; the Ministry of Education and Science of the Russian Federation (project code RFMEFI61917X0007), as well as by the Initiative Program in the frames of the State Tasks 0082-20140004 and 0082-2014-0007 "Fundamental regularities of heterogeneous and homogeneous catalysis"; the Program of Fundamental Research of the Russian Academy of Sciences for 2013-2020 on the research issue of IChP RAS No. 47.16.; and the A.N. Nesmeyanov Institute RAS (Institute of Organoelement Compounds, Russian Academy of Sciences).

Conflicts of Interest: The authors declare no conflict of interest.

Sample Availability: Samples of the compounds 1-3 are available from the authors.

\section{References}

1. Butler, A.; Carrano, C. Coordination chemistry of vanadium in biological systems. Coord. Chem. Rev. 1991, 109, 61-105. [CrossRef]

2. Chatterjee, M.; Ghosh, S.; Wu, B.-M.; Mak, T.C.W. A structural and electrochemical study of some oxovanadium (IV) heterochelate complexes. Polyhedron 1998, 17, 1369-1374. [CrossRef]

3. Liu, S.-X.; Gao, S. Synthesis, crystal structure and spectral properties of VO (acetylacetone benzoylhydrazone) (8-quinolinol). Polyhedron 1998, 17, 81-84. [CrossRef]

4. Bhattacharyya, S.; Mukhopadhyay, S.; Samanta, S.; Weakley, T.J.R.; Chaudhury, M. Synthesis, characterization, and reactivity of mononuclear $\mathrm{O}, \mathrm{N}$-chelated vanadium(IV) and -(III) complexes of methyl 2-aminocyclopent-1-ene-1-dithiocarboxylate based ligand: Reporting an example of conformational isomerism in the solid state. Inorg. Chem. 2002, 41, 2433-2440. [CrossRef] [PubMed]

5. Horn, A., Jr.; Filgueiras, C.A.L.; Wardell, J.L.; Herbst, M.H.; Vugman, N.V.; Santos, P.S.; Lopes, J.G.S.; Howie, R.A. A fresh look into VO (salen) chemistry: Synthesis, spectroscopy, electrochemistry and crystal structure of $\left[\mathrm{VO}(\mathrm{salen})\left(\mathrm{H}_{2} \mathrm{O}\right)\right] \mathrm{Br} \cdot 0.5 \mathrm{CH} \mathrm{H}_{3} \mathrm{CN}$. Inorg. Chim. Acta 2004, 357, 4240-4246. [CrossRef]

6. Elias, H.; Schwartze-Eidam, S.; Wannowius, K.J. Kinetics and mechanism of ligand substitution in bis(N-alkylsalicylaldiminato)ox ovanadium(IV) complexes. Inorg. Chem. 2003, 42, 2878-2885. [CrossRef] [PubMed]

7. Correia, I.; Pessoa, J.C.; Duarte, M.T.; Henriques, R.T.; Fátima, M.; Piedade, M.; Veiros, L.F.; Jakusch, T.; Kiss, T.; Dörnyei, Á.; et al. $\mathrm{N}, \mathrm{N}^{\prime}$-ethylenebis(pyridoxylideneiminato) and $\mathrm{N}, \mathrm{N}^{\prime}$-ethylenebis(pyridoxylaminato): Synthesis, characterization, potentiometric, spectroscopic, and DFT studies of their vanadium(IV) and vanadium(V) complexes. Chem. Eur. J. 2004, 10, 2301-2317. [CrossRef]

8. Yucesan, G.; Armatas, N.G.; Zubieta, J. Hydrothermal synthesis of molecular oxovanadium compounds. The crystal and molecular structures of $\left[\mathrm{VO}_{2}(\right.$ terpy $\left.)\right] \mathrm{NO}_{3},\left[\mathrm{VO}\left(\right.\right.$ terpy) $\left.\left(\mathrm{OH}_{3} \mathrm{PC}_{6} \mathrm{H}_{5}\right)_{2}\right],\left[\left\{\mathrm{Cu}\left(\mathrm{H}_{2} \mathrm{O}\right)(\right.\right.$ terpy $\left.\left.)\right\} \mathrm{V}_{2} \mathrm{O}_{6}\right],\left[\{\mathrm{Cu}(\mathrm{ttbterpy})\} \mathrm{V}_{2} \mathrm{O}_{6}\right]$ and $\left[\{\mathrm{Cu}\right.$ (ttbterpy) $\left.\} \mathrm{VO}_{2}\left(\mathrm{HO}_{3} \mathrm{PCH}_{2} \mathrm{PO}_{3}\right)\right] \cdot \mathrm{H}_{2} \mathrm{O}$ (terpy $=2,2^{\prime}: 6^{\prime}, 2^{\prime \prime}$-terpyridine; ttbterpy $=4,4^{\prime}, 4^{\prime \prime}$-tri-tert-butyl-2,2' $2^{\prime}, 2^{\prime \prime}$-terpyridine) . Inorg. Chim. Acta 2006, 359, 4557-4564.

9. Ghosh, T.; Mondal, B.; Ghosh, T.; Sutradhar, M.; Mukherjee, G.; Drew, M.G.B. Synthesis, structure, solution chemistry and the electronic effect of para substituents on the vanadium center in a family of mixed-ligand $\left[\mathrm{V}^{\mathrm{V}} \mathrm{O}(\mathrm{ONO})(\mathrm{ON})\right]$ complexes. Inorg. Chim. Acta 2007, 360, 1753-1761. [CrossRef]

10. Rubčić, M.; Milić, D.; Horvat, G.; Đilović, I.; Galić, N.; Tomšić, V.; Cindrić, M. Vanadium-induced formation of thiadiazole and thiazoline compounds. Mononuclear and dinuclear oxovanadium $(\mathrm{V})$ complexes with open-chain and cyclized thiosemicarbazone ligands. Dalton Trans. 2009, 2009, 9914-9923. [CrossRef]

11. Hakimi, M.; Kukovec, B.-M.; Rezvaninezhad, M.; Schuh, E.; Mohr, F. Preparation, structural and spectroscopic characterization of vanadium(IV) and vanadium(V) complexes with dipicolinic acid. Z. Anorg. Allg. Chem. 2011, 637, 2157-2162. [CrossRef]

12. Sanna, D.; Buglyó, P.; Tomaz, A.I.; Costa Pessoa, J.; Borović, S.; Micerae, G.; Garribba, E. V ${ }^{\mathrm{IV}} \mathrm{O}$ and Cu $\mathrm{Cu}^{\mathrm{II}}$ complexation by ligands based on pyridine nitrogen donors. Dalton Trans. 2012, 41, 12824-12838. [CrossRef] [PubMed]

13. Tutusaus, O.; Ni, C.; Szymczak, N.K. A Transition metal Lewis acid/base triad system for cooperative substrate binding. J. Am. Chem. Soc. 2013, 135, 3403-3406. [CrossRef]

14. Bhattacharya, K.; Maity, M.; Abtab, S.M.T.; Majee, M.C.; Chaudhury, M. Homo- and heterometal complexes of oxido-metal ions with a triangular $[\mathrm{V}(\mathrm{V}) \mathrm{O}-\mathrm{MO}-\mathrm{V}(\mathrm{V}) \mathrm{O}][\mathrm{M}=\mathrm{V}(\mathrm{IV})$ and $\mathrm{Re}(\mathrm{V})]$ core: Reporting mixed-oxidation oxido-vanadium(V/IV/V) compounds with valence trapped structures. Inorg. Chem. 2013, 52, 9597-9605. [CrossRef]

15. Sheng, G.-H.; Cheng, X.-S.; You, Z.-L.; Zhu, H.-L. Two isomeric structures of oxovanadium(V) complexes with hydrazone and 8-hydroxyquinoline ligands. J. Struct. Chem. 2015, 56, 942-947. [CrossRef]

16. Sheppard, B.J.H.; Shaver, M.P.; Pearson, J.K. Assessment and application of density functional theory for the prediction of structure and reactivity of vanadium complexes. J. Phys. Chem. A 2015, 119, 8537-8546. [CrossRef] [PubMed]

17. Sutradhar, M.; Pombeiro, A.J.L. Coordination chemistry of non-oxido, oxido and dioxidovanadium(IV/V) complexes with azine fragment ligands. Coord. Chem. Rev. 2014, 265, 89-124. [CrossRef] 
18. Kolesa-Dobravc, T.; Lodyga-Chruscinska, E.; Symonowicz, M.; Sanna, D.; Meden, A.; Perdih, F.; Garribba, E. Synthesis and characterization of $\mathrm{V}(\mathrm{IV}) \mathrm{O}$ complexes of picolinate and pyrazine derivatives. Behavior in the solid state and aqueous solution and biotransformation in the presence of blood plasma proteins. Inorg. Chem. 2014, 53, 7960-7976. [CrossRef]

19. Chang, Y.-P.; Furness, L.; Levason, W.; Reid, G.; Zhang, W. Complexes of vanadium(IV) oxide difluoride with neutral N- and O-donor ligands. J. Fluor. Chem. 2016, 191, 149-160. [CrossRef]

20. Dash, S.P.; Majumder, S.; Banerjee, A.; Fernanda, M.; Carvalho, N.N.; Adaão, P.; Costa Pessoa, J.; Brzezinski, K.; Garribba, E.; Reuter, H.; et al. Chemistry of monomeric and dinuclear non-oxido vanadium(IV) and oxidovanadium(V) aroylazine complexes: Exploring solution behavior. Inorg. Chem. 2016, 55, 1165-1182. [CrossRef]

21. Süss-Fink, G.; Gonzalez Cuervo, L.; Therrien, B.; Stoeckli-Evans, H.; Shul'pin, G.B. Mono and oligonuclear vanadium complexes as catalysts for alkane oxidation: Synthesis, molecular structure, and catalytic potential. Inorg. Chim. Acta 2004, 357, 475-484. [CrossRef]

22. Crans, D.C.; Smee, J.J.; Gaidamauskas, E.; Yang, L. The chemistry and biochemistry of vanadium and the biological activities exerted by vanadium compounds. Chem. Rev. 2004, 104, 849-902. [CrossRef] [PubMed]

23. Hanson, S.K.; Baker, R.T.; Gordon, J.C.; Scott, B.L.; Silks, L.A.; Thorn, D.L. Mechanism of alcohol oxidation by dipicolinate vanadium (V): Unexpected role of pyridine. J. Am. Chem. Soc. 2010, 132, 17804-17816. [CrossRef]

24. Zhang, G.; Scott, B.L.; Wu, R.; Silks, L.A.; Hanson, S.K. Aerobic oxidation reactions catalyzed by vanadium complexes of bis (phenolate) ligands. Inorg. Chem. 2012, 51, 7354-7361. [CrossRef]

25. Grivani, G.; Ghavami, A.; Kučeráková, M.; Dušek, M.; Dehno Khalaji, A. Synthesis, characterization, crystal structure determination, thermal study and catalytic activity of a new oxidovanadium Schiff base complex. J. Mol. Struct. 2014, 1076, 326-332. [CrossRef]

26. Tuskaev, V.A.; Kolosov, N.A.; Kurmaev, D.A.; Gagieva, S.C.; Khrustalev, V.N.; Ikonnikov, N.S.; Efimov, N.N.; Ugolkova, E.A.; Minin, V.V.; Bulychev, B.M. Vanadium (IV), (V) coordination compounds with 8-hydroxyquinoline derivative: Synthesis, structure and catalytic activity in the polymerization of ethylene. J. Organomet. Chem. 2015, 798, 393-400. [CrossRef]

27. Mandal, M.; Nagaraju, V.; Karunakar, G.V.; Sarma, B.; Borah, B.J.; Bania, K.K. Electronic, conjugation, and confinement effects on structure, redox, and catalytic behavior of oxido-vanadium (IV) and-(V) chiral Schiff base complexes. J. Phys. Chem. C 2015, 119, 28854-28870. [CrossRef]

28. Sutradhar, M.; Martins, L.M.; Guedes da Silva, M.F.C.; Pombeiro, A.J.L. Oxidovanadium complexes with tridentate aroylhydrazone as catalyst precursors for solvent-free microwave-assisted oxidation of alcohols. Appl. Catal. A Gen. 2015, 493, 50-57. [CrossRef]

29. Chieregato, A.; Lopez Nieto, J.M.; Cavani, F. Mixed-oxide catalysts with vanadium as the key element for gas-phase reactions. Coord. Chem. Rev. 2015, 301-302, 3-23. [CrossRef]

30. Elkurtehi, A.I.; Walsh, A.G.; Dawe, L.N.; Kerton, F.M. Vanadium Aminophenolate complexes and their catalytic activity in aerobic and $\mathrm{H}_{2} \mathrm{O}_{2}$-mediated oxidation reactions. Eur. J. Inorg. Chem. 2016, 2016, 3123-3130. [CrossRef]

31. Wang, Y.; Lin, X.-M.; Bai, F.-Y.; Sun, L.-X. Novel vanadium complexes with rigid carboxylate ligands: Synthesis, structure and catalytic bromine dynamics of phenol red. J. Mol. Struct. 2017, 1149, 379-386. [CrossRef]

32. Schmidt, A.-C.; Hermsen, M.; Rominger, F.; Dehn, R.; Teles, J.H.; Schaäfer, A.; Trapp, O.; Schaub, T. Synthesis of mono-and dinuclear vanadium complexes and their reactivity toward dehydroperoxidation of alkyl hydroperoxides. Inorg. Chem. 2017, 56, 1319-1332. [CrossRef]

33. Pessoa, J.C. Thirty years through vanadium chemistry. J. Inorg. Biochem. 2015, 147, 4-24. [CrossRef] [PubMed]

34. Rehder, D. The coordination chemistry of vanadium as related to its biological functions. Coord. Chem. Rev. 1999, 182, 297-322. [CrossRef]

35. Xie, M.-J.; Niu, Y.-F.; Yang, X.-D.; Liu, W.-P.; Li, L.; Gao, L.-H.; Yan, S.-P.; Meng, Z.-H. Effect of the chloro-substitution on lowering diabetic hyperglycemia of vanadium complexes with their permeability and cytotoxicity. Eur. J. Med. Chem. 2010, 45, 6077-6084. [CrossRef]

36. Banik, B.; Sasmal, P.K.; Roy, S.; Majumdar, R.; Dighe, R.R.; Chakravarty, A.R. Terpyridine oxovanadium (IV) complexes of phenanthroline bases for cellular imaging and photocytotoxicity in HeLa cells. Eur. J. Inorg. Chem. 2011, 2011, 1425-1435. [CrossRef]

37. Correia, I.; Adão, P.; Roy, S.; Wahba, M.; Matos, C.; Maurya, M.R.; Marques, F.; Pavan, F.R.; Leite, C.Q.F.; Avecilla, F.; et al. Hydroxyquinoline derived vanadium(IV and V) and copper(II) complexes as potential anti-tuberculosis and anti-tumor agents. J. Inorg. Biochem. 2014, 141, 83-93. [CrossRef]

38. Fik, M.A.; Gorczyński, A.; Kubicki, M.; Hnatejko, Z.; Wadas, A.; Kulesza, P.J.; Lewińska, A.; Giel-Pietraszuk, M.; Wyszko, E.; Patroniak, V. New vanadium complexes with $6,6^{\prime \prime}$-dimethyl-2,2': $6^{\prime}, 2^{\prime \prime}$-terpyridine in terms of structure and biological properties. Polyhedron 2015, 97, 83-93. [CrossRef]

39. Kioseoglou, E.; Petanidis, S.; Gabriel, C.; Salifoglou, A. The chemistry and biology of vanadium compounds in cancer therapeutics. Coord. Chem. Rev. 2015, 301-302, 87-105. [CrossRef]

40. Reytman, L.; Braitbard, O.; Hochman, J.; Tshuva, E.Y. Highly effective and hydrolytically stable vanadium (V) amino phenolato antitumor agents. Inorg. Chem. 2016, 55, 610-618. [CrossRef]

41. Kumar, A.; Pant, I.; Dixit, A.; Banerjee, S.; Banik, B.; Saha, R.; Kondaiah, P.; Chakravarty, A.R. Terpyridyl oxovanadium (IV) complexes for DNA crosslinking and mito-targeted photocytotoxicity. J. Inorg. Biochem. 2017, 174, 45-54. [CrossRef] [PubMed] 
42. Hong, X.-L.; Liu, L.-J.; Lu, W.-G.; Wang, X.-B. A vanadium (V) terpyridine complex: Synthesis, characterization, cytotoxicity in vitro and induction of apoptosis in cancer cells. Transit. Met. Chem. 2017, 42, 459-467. [CrossRef]

43. Ni, L.; Zhao, H.; Tao, L.; Li, X.; Zhou, Z.; Sun, Y.; Chen, C.; Wei, D.; Liu, Y.; Diao, G. Synthesis, in vitro cytotoxicity, and structure-activity relationships (SAR) of multidentate oxidovanadium(IV) complexes as anticancer agents. Dalton Trans. 2018, 47, 10035-10045. [CrossRef]

44. El-Deen, I.M.; Shoair, A.F.; El-Bindary, M.A. Synthesis, characterization and biological properties of oxovanadium(IV) complexes. J. Mol. Struct. 2019, 1180, 420-437. [CrossRef]

45. Floris, B.; Sabuzi, F.; Coletti, A.; Conte, V. Sustainable vanadium-catalyzed oxidation of organic substrates with $\mathrm{H}_{2} \mathrm{O}_{2}$. Catal. Today 2017, 285, 49-56. [CrossRef]

46. Hasnaoui, A.; Idouhli, R.; Nayad, A.; Ouahine, H.; Khadiri, M.-E.; Abouelfidab, A.; Elfirdoussi, L.; Ait Ali, M. Di-nuclear water-soluble oxovanadium (V) Schiff base complexes: Electrochemical properties and catalytic oxidation. Inorg. Chem. Commun. 2020, 119, 108134.

47. Crans, D. Chemistry and insulin-like properties of vanadium (IV) and vanadium (V) compounds. J. Inorg. Biochem. 2000, 80, 123-131. [CrossRef]

48. Banik, B.; Somyajit, K.; Koleyc, D.; Nagaraju, G.; Chakravarty, A.R. Cellular uptake and remarkable photocytotoxicity of pyrenylter pyridine oxovanadium(IV) complexes of dipyridophenazine bases. Inorg. Chim. Acta 2012, 393, 284-293. [CrossRef]

49. Banik, B.; Somyajit, K.; Nagaraju, G.; Chakravarty, A.R. Oxovanadium (IV) catecholates of terpyridine bases for cellular imaging and photocytotoxicity in red light. RSC Adv. 2014, 4, 40120-40131. [CrossRef]

50. Banik, B.; Somyajit, K.; Nagaraju, G.; Chakravarty, A.R. Oxovanadium (IV) complexes of curcumin for cellular imaging and mitochondria targeted photocytotoxicity. Dalton Trans. 2014, 43, 13358-13369. [CrossRef]

51. Banik, B.; Somyajit, K.; Hussain, A.; Nagaraju, G.; Chakravarty, A.R. Carbohydrate-appended photocytotoxic (imidazophenanthr oline)-oxovanadium (IV) complexes for cellular targeting and imaging. Dalton Trans. 2014, 43, 1321-1331. [CrossRef]

52. Balaji, B.; Balakrishnan, B.; Perumalla, S.; Karande, A.A.; Chakravarty, A.R. Photoactivated cytotoxicity of ferrocenyl-terpyridine oxovanadium(IV) complexes of curcuminoids. Eur. J. Med. Chem. 2014, 85, 458-467. [CrossRef]

53. Balaji, B.; Balakrishnan, B.; Perumalla, S.; Karande, A.A.; Chakravarty, A.R. Photocytotoxic oxovanadium(IV) complexes of ferrocenyl-terpyridine and acetylacetonate derivatives. Eur. J. Med. Chem. 2015, 92, 332-341. [CrossRef] [PubMed]

54. Levina, A.; McLeod, A.I.; Gasparini, S.J.; Nguyen, A.; Manori De Silva, W.G.; Aitken, J.B.; Harris, H.H.; Glover, C.; Johannessen, B.; Lay, P.A. Reactivity and speciation of anti-diabetic vanadium complexes in whole blood and its components: The important role of red blood cells. Inorg. Chem. 2015, 54, 7753-7766. [CrossRef]

55. Pessoa, J.C.; Etcheverry, S.; Gambino, D. Vanadium compounds in medicine. Coord. Chem. Rev. 2015, 301-302, 24-48. [CrossRef] [PubMed]

56. Thompson, K.H.; Lichter, J.; LeBel, C.; Scaife, M.C.; McNeill, J.H.; Orvig, C. Vanadium treatment of type 2 diabetes: A view to the future. J. Inorg. Biochem. 2009, 103, 554-558. [CrossRef] [PubMed]

57. Fukui, K.; Fujisawa, Y.; Ohya-Nishiguchi, H.; Kamada, H.; Sakurai, H. In vivo coordination structural changes of a potent insulin-mimetic agent, bis(picolinato)oxovanadium(IV), studied by electron spin-echo envelope modulation spectroscopy. J. Inorg. Biochem. 1999, 77, 215-224. [CrossRef]

58. Thompson, K.H.; McNeill, J.H.; Orvig, C. Vanadium compounds as insulin mimics. Chem. Rev. 1999, 99, 2561-2571. [CrossRef] [PubMed]

59. Thompson, K.H.; Orvig, C. Coordination chemistry of vanadium in metallopharmaceutical candidate compounds. Coord. Chem. Rev. 2001, 219-221, 1033-1053. [CrossRef]

60. Sakurai, H.; Kojima, M.; Yoshikawa, Y.; Kawabe, K.; Yasui, H. Antidiabetic vanadium (IV) and zinc (II) complexes. Coord. Chem. Rev. 2002, 226, 187-198. [CrossRef]

61. Kiss, T.; Jakusch, T.; Hollender, D.; Enyedy, EÉA.; Horvath, L. Comparative studies on the biospeciation of antidiabetic VO(IV) and $\mathrm{Zn}(\mathrm{II})$ complexes. J. Inorg. Biochem. 2009, 103, 527-535. [CrossRef] [PubMed]

62. Choroba, K.; Raposo, L.R.; Palion-Gazda, J.; Malicka, E.; Erfurt, K.; Machura, B.; Fernandes, A.R. In vitro antiproliferative effect of vanadium complexes bearing 8-hydroxyquinoline-based ligands-the substituent effect. Dalton Trans. 2020, 49, 6596-6606. [CrossRef] [PubMed]

63. Gryca, I.; Czerwińska, K.; Machura, B.; Chrobok, A.; Shul'pina, L.S.; Kuznetsov, M.L.; Nesterov, D.S.; Kozlov, Y.N.; Pombeiro, A.J.L.; Varyan, I.A.; et al. High catalytic activity of vanadium complexes in alkane oxidations with hydrogen peroxide: An effect of 8-hydroxyquinoline derivatives as noninnocent ligands. Inorg. Chem. 2018, 57, 1824-1839. [CrossRef] [PubMed]

64. Shiro, M.; Fernando, Q. Structures of two five-coordinated metal chelates of 2-methyl-8-quinolinol. Anal. Chem. 1971, 43, 1222-1230. [CrossRef]

65. Addison, A.W.; Rao, T.N. Synthesis, structure, and spectroscopic properties of copper(II) compounds containing nitrogen-sulphur donor ligands-The crystal and molecular structure of aqua [1,7-bis(N-methylbenzimidazol-2'-yl)-2,6-dithiaheptane]copper(II) perchlorate. J. Chem. Soc. Dalton Trans. 1984, 1984, 1349-1356. [CrossRef]

66. Groom, C.R.; Bruno, I.J.; Lightfoot, M.P.; Ward, S.C. The Cambridge structural database. Acta Crystallogr. Sect. B Struct. Sci. Cryst. Eng. Mater. 2016, 72, 171-179. [CrossRef] 
67. Menati, S.; Rudbari, H.A.; Khorshidifard, M.; Jalilian, F. A new oxovanadium(IV) complex containing an O,N-bidentate Schiff base ligand: Synthesis at ambient temperature, characterization, crystal structure and catalytic performance in selective oxidation of sulfides to sulfones using $\mathrm{H}_{2} \mathrm{O}_{2}$ under solvent-free conditions. J. Mol. Struct. 2016, 1103, 94-102.

68. Grivani, G.; Khalaji, A.D.; Tahmasebi, V.; Gotoh, K.; Ishida, H. Synthesis, characterization and crystal structures of new bidentate Schiff base ligand and its vanadium(IV) complex: The catalytic activity of vanadyl complex in epoxidation of alkenes. Polyhedron 2012, 31, 265-271. [CrossRef]

69. Burgess, J.; Fawcett, J.; Palma, V.; Gilani, S.R. Fluoro derivatives of bis (salicylideneaminato-N, O) copper(II) and-oxovanadium(IV). Acta Crystallogr. Sect. C Struct. Sci. Cryst. Eng. Mater. 2001, 57, 277-280. [CrossRef]

70. Santoni, G.; Rehder, D. Structural models for the reduced form of vanadate-dependent peroxidases: Vanadyl complexes with bidentate chiral Schiff base ligands. J. Inorg. Biochem. 2004, 98, 758-764. [CrossRef]

71. Cornman, C.R.; Geiser-Bush, K.M.; Rowley, S.P.; Boyle, P.D. Structural and electron paramagnetic resonance studies of the square pyramidal to trigonal bipyramidal distortion of vanadyl complexes containing sterically crowded schiff base ligands. Inorg. Chem. 1997, 36, 6401-6408. [CrossRef]

72. Pasquali, M.; Marchetti, F.; Floriani, C.; Merlino, S. Oxovanadium(IV) complexes containing bidentate Schiff-base ligands: Synthesis and structural and spectroscopic data. J. Chem. Soc. Dalton Trans. 1977, 1977, 139-144. [CrossRef]

73. Cashin, B.; Cunningham, D.; Daly, P.; McArdle, P.; Munroe, M.; Chonchubhair, N.N. Donor properties of the vanadyl ion: Reactions of vanadyl salicylaldimine $\beta$-ketimine and acetylacetonato complexes with groups 14 and 15 Lewis acids. Inorg. Chem. 2002, 41, 773-782. [CrossRef] [PubMed]

74. Hsuan, R.E.; Hughes, J.E.; Miller, T.H.; Shaikh, N.; Cunningham, P.H.M.; O'Connor, A.E.; Tidey, J.P.; Blake, A.J. Crystal structure of $\left\{2,2^{\prime}\right.$-[ethylenebis(nitrilomethanylylidene)]diphenolato- $\left./ 4 \mathrm{O}, \mathrm{N}^{\prime} \mathrm{N}^{\prime}, \mathrm{O}^{\prime}\right\}$ oxidovanadium(IV) methanol monosolvate. Acta Crystallogr. Sect. E Struct. Sci. Cryst. Eng. Mater 2014, 70, m380-m381.

75. Nguyen, M.T.; Jones, R.A.; Holliday, B.J. Effect of conjugation length and metal-backbone interactions on charge transport properties of conducting metallopolymers. Polym. Chem. 2017, 8, 4359-4367. [CrossRef]

76. Carter, E.; Fallis, I.A.; Kariuki, B.M.; Morgan, I.R.; Murphy, D.M.; Tatchell, T.; Van Doorslaer, S.; Vinck, E. Structure and pulsed EPR characterization of N,N'-bis(5-tert-butylsalicylidene)-1,2-cyclohexanediamino-vanadium(IV) oxide and its adducts with propylene oxide. Dalton Trans. 2011, 40,7454-7462. [CrossRef]

77. Hoshina, G.; Tsuchimoto, M.; Ohba, S.; Nakajima, K.; Uekusa, H.; Ohashi, Y.; Ishida, H.; Kojima, M. Thermal Dehydrogenation of Oxovanadium(IV) Complexes with Schiff Base Ligands Derived from meso-1,2-Diphenyl-1,2-ethanediamine in the Solid State. Inorg. Chem. 1998, 37, 142-145. [CrossRef]

78. Hoshina, G.; Tsuchimoto, M.; Ohba, S. exo-[(RS,SR)-N,N'-Bis(salicylidene)-2,3-butanediaminato]oxovanadium(IV). Acta Crystallogr. Sect. C Struct. Sci. Cryst. Eng. Mater. 1999, 55, 1082-1084. [CrossRef]

79. Bonadies, J.A.; Butler, W.M.; Pecoraro, V.L.; Carrano, C.J. Novel reactivity patterns of (N, $\mathrm{N}^{\prime}$-ethylenebis(salicylideneaminato))oxo vanadium(IV) in strongly acidic media. Inorg. Chem. 1987, 26, 1218-1222. [CrossRef]

80. Hoshina, G.; Tsuchimoto, M.; Ohba, S. endo-\{6,6'-Diethoxy-2,2'-[(R)-propane-1,2-diylbis(nitrilomethylidene)]diphenolato$O, N, N^{\prime}, O^{\prime}$ \}oxovanadium(IV). Acta Crystallogr. Sect. C Struct. Sci. Cryst. Eng. Mater. 1999, 55, 1812-1813. [CrossRef]

81. Bolm, C.; Bienewald, F.; Harms, K. Syntheses and vanadium complex of salen-like bissulfoximines. Synlett 1996, 8, 775-776. [CrossRef]

82. Oyaizu, K.; Dewi, E.L.; Tsuchida, E. Coordination of $\mathrm{BF}^{4-}$ to Oxovanadium(V) Complexes, Evidenced by the Redox Potential of Oxovanadium(IV/V) Couples in $\mathrm{CH}_{2} \mathrm{Cl}_{2}$. Inorg. Chem. 2003, 42, 1070-1075. [CrossRef] [PubMed]

83. Chasteen, N.D. Biological Magnetic Resonance; Berliner, L.J., Reuben, J., Eds.; Plenum: New York, NY, USA, 1981; Volume 3, pp. 53-119.

84. Velayutham, M.; Varghese, B.; Subramanian, S. Magneto-structural correlation studies of a ferromagnetically coupled dinuclear vanadium(IV) complex. Single-crystal EPR study. Inorg. Chem. 1998, 37, 1336-1340. [CrossRef] [PubMed]

85. Shulpin, B.; Attanasio, D.; Suber, L. Efficient $\mathrm{H}_{2} \mathrm{O}_{2}$ oxidation of alkanes and arenes to alkyl peroxides and phenols catalyzed by the system vanadate-pyrazine-2-carboxylic acid. J. Catal. 1993, 142, 147-152. [CrossRef]

86. Kirillov, A.M.; Shul'pin, G.B. Pyrazinecarboxylic acid and analogs: Highly efficient co-catalysts in the metal-complex-catalyzed oxidation of organic compounds. Coord. Chem. Rev. 2013, 257, 732-754. [CrossRef]

87. Levitsky, M.M.; Bilyachenko, A.N.; Shul'pin, G.B. Oxidation of $\mathrm{CH}$ compounds with peroxides catalyzed by polynuclear transition metal complexes in Si-or Ge-sesquioxane frameworks: A review. J. Organomet. Chem. 2017, 849-850, 201-218. [CrossRef]

88. Shul'pin, B.; Shul'pina, L.S. Vanadium Catalysis; Sutradhar, M., da Silva, J.A.L., Pombeiro, A.J.L., Eds.; Royal Society of Chemistry: London, UK, 2020; Chapter 4; pp. 72-96.

89. Shul'pin, G.B.; Süss-Fink, G. Oxidations by the reagent " $\mathrm{H}_{2} \mathrm{O}_{2}$-vanadium complex-pyrazine-2-carboxylic acid". Part 4. Oxidation of alkanes, benzene and alcohols by an adduct of $\mathrm{H}_{2} \mathrm{O}_{2}$ with urea. J. Chem. Soc. Perkin Trans. 2 1995, 7, 1459-1463. [CrossRef]

90. Shul'pin, G.B.; Drago, R.S.; Gonzalez, M. Oxidations by a " $\mathrm{H}_{2} \mathrm{O}_{2}$-vanadium complex-pyrazine-2-carboxylic acid" reagent. Part 5 . Oxidation of lower alkanes with the formation of carbonyl compounds". Russ. Chem. Bull. 1996, 45, 2386-2388. [CrossRef]

91. Shul'pin, G.B.; Guerreiro, M.C.; Schuchardt, U. Oxidations by the reagent $\mathrm{O}_{2}-\mathrm{H}_{2} \mathrm{O}_{2}$-vanadium complex-pyrazine-2-carboxylic acid. Part 7. Hydroperoxidation of higher alkanes. Tetrahedron 1996, 52, 13051-13062. [CrossRef]

92. Shul'pin, G.B.; Druzhinina, A.N.; Nizova, G.V. Oxidation with the $\mathrm{H}_{2} \mathrm{O}_{2}-\mathrm{VO}_{3}{ }^{-}$-pyrazine-2-carboxylic acid reagent. Part 2 . Oxidation of alcohols and aromatic hydrocarbons. Russ. Chem. Bull. 1993, 42, 1327-1329. 
93. Shul'pin, G.B.; Nesterov, D.S.; Shul'pina, L.S.; Pombeiro, A.J.L. A hydroperoxo-rebound mechanism of alkane oxidation with hydrogen peroxide catalyzed by binuclear manganese(IV) complex in the presence of an acid with involvement of atmospheric dioxygen. Inorg. Chim. Acta 2017, 455, 666-676. [CrossRef]

94. Ertik, O.; Kalındemirtaş, F.D.; Kaya, B.; Yanardag, R.; Erdem Kuruca, S.; Şahin, O.; Ülküseven, B. Oxovanadium(IV) complexes with tetradentate thiosemicarbazones. Synthesis, characterization, anticancer enzyme inhibition and in vitro cytotoxicity on breast cancer cells. Polyhedron 2021, 202, 115192. [CrossRef]

95. Sutradhar, M.; Alegria, E.; Ferretti, F.; Raposo, L.R.; Guedes da Silva, M.F.C.; Baptista, P.V.; Fernandes, A.R.; Pombeiro, A.J.L. Antiproliferative activity of heterometallic sodium and potassium-dioxidovanadium (V) polymers. J. Inorg. Biochem. 2019, 200, 110811. [CrossRef]

96. Yang, X.G.; Wang, K.; Lu, J.F.; Crans, D.C. Membrane transport of vanadium compounds and the interaction with the erythrocyte membrane. Coord. Chem. Rev. 2003, 237, 103-111. [CrossRef]

97. Reigosa-Chamorro, F.; Raposo, L.R.; Munin-Cruz, P.; Pereira, M.T.; Roma-Rodrigues, C.; Baptista, P.V.; Fernandes, A.R.; Vila, J.M. In Vitro and In Vivo Effect of Palladacycles: Targeting A2780 Ovarian Carcinoma Cells and Modulation of Angiogenesis. Inorg. Chem. 2021, 60, 3939-3951. [CrossRef] [PubMed]

98. Nycz, J.E.; Szala, M.; Malecki, G.J.; Nowak, M.; Kusz, J. Synthesis, spectroscopy and computational studies of selected hydroxyquinolines and their analogues. Spectrochim. Acta Part A 2014, 117, 351. [CrossRef]

99. CrysAlisPRO; Oxford Diffraction/Agilent Technologies UK Ltd.: Yarnton, UK, 2014.

100. Sheldrick, G.M. Crystal structure refinement with SHELXL. Acta Crystallogr. Sect. C Struct. Sci. Cryst. Eng. Mater. 2015, 71, 3-8. [CrossRef] [PubMed]

101. Sanna, D.; Várnagy, K.; Lihi, N.; Micera, G.; Garribba, E. Formation of new non-oxido vanadium(IV) species in aqueous solution and in the solid state by tridentate $(\mathrm{O}, \mathrm{N}, \mathrm{O})$ ligands and rationalization of their EPR behavior. Inorg. Chem. 2013, 52, 8202-8213. [CrossRef]

102. WINEPR SimFonia, Version 1.25; Bruker Analytische, Messtechnik GmbH: Karlshruhe, Germany, 1996.

103. Raposo, L.R.; Silva, A.; Silva, D.; Roma-Rodrigues, C.; Espadinha, M.; Baptista, P.V.; Santos, M.M.M.; Fernandes, A.R. Exploiting the antiproliferative potential of spiropyrazoline oxindoles in a human ovarian cancer cell line. Bioorg. Med. Chem. 2021, 30, 115880. [CrossRef]

104. Choroba, K.; Machura, B.; Szlapa-Kula, A.; Malecki, J.G.; Raposo, L.; Roma-Rodrigues, C.; Cordeiro, S.; Baptista, P.V.; Fernandes, A.R. Square planar Au (III), Pt (II) and Cu (II) complexes with quinoline-substituted 2, 2': $6^{\prime}, 2^{\prime \prime}$-terpyridine ligands: From in vitro to in vivo biological properties. Eur. J. Med. Chem. 2021, 218, 113404. [CrossRef] [PubMed]

105. Reers, M.; Smith, T.W.; Chen, L.B. J-aggregate formation of a carbocyanine as a quantitative fluorescent indicator of membrane potential. Biochemistry 1991, 30, 4480-4486. [CrossRef] [PubMed]

106. Shul'pin, G.B. Metal-catalyzed hydrocarbon oxygenations in solutions: The dramatic role of additives: A review. J. Mol. Catal. A Chem. 2002, 189, 39-66. [CrossRef]

107. Shul'pin, G.B.; Kozlov, Y.N.; Shul'pina, L.S.; Petrovskiy, P.V. Oxidation of alkanes and alcohols with hydrogen peroxide catalyzed by complex Os3(CO)10( $\mu-\mathrm{H}) 2$. Appl. Organometal. Chem. 2010, 24, 464-472. [CrossRef] 